\title{
Measurements of total hydroxyl radical reactivity during CABINEX 2009 - Part 1: field measurements
}

\author{
R. F. Hansen ${ }^{1,2, *}$, S. M. Griffith ${ }^{2,3}$, S. Dusanter ${ }^{3,4,5}$, P. S. Rickly ${ }^{2,3}$, P. S. Stevens ${ }^{1,2,3}$, S. B. Bertman ${ }^{6}$, M. A. Carroll ${ }^{7,8}$, \\ M. H. Erickson ${ }^{9}$, J. H. Flynn ${ }^{10}$, N. Grossberg ${ }^{10}$, B. T. Jobson ${ }^{9}$, B. L. Lefer ${ }^{10}$, and H. W. Wallace \\ ${ }^{1}$ Department of Chemistry, Indiana University, Bloomington, IN, USA \\ ${ }^{2}$ Center for Research in Environmental Science, Indiana University, Bloomington, IN, USA \\ ${ }^{3}$ School of Public and Environmental Affairs, Indiana University, Bloomington, IN, USA \\ ${ }^{4}$ Mines Douai, CE, F59508, Douai, France \\ ${ }^{5}$ Université Lille Nord de France, 59000, Lille, France \\ ${ }^{6}$ Department of Chemistry, Western Michigan University, Kalamazoo, MI, USA \\ ${ }^{7}$ Department of Chemistry, University of Michigan, Ann Arbor, MI, USA \\ ${ }^{8}$ Department of Atmospheric, Oceanic, and Space Sciences, University of Michigan, Ann Arbor, MI, USA \\ ${ }^{9}$ Department of Civil and Environmental Engineering, Washington State University, Pullman, WA, USA \\ ${ }^{10}$ Department of Earth and Atmospheric Sciences, University of Houston, Houston, TX, USA \\ *now at: School of Chemistry, University of Leeds, Woodhouse Lane, Leeds, LS2 9JT, UK
}

Correspondence to: R. F. Hansen (rfhansen@indiana.edu)

Received: 31 May 2013 - Published in Atmos. Chem. Phys. Discuss.: 28 June 2013

Revised: 8 January 2014 - Accepted: 6 February 2014 - Published: 21 March 2014

\begin{abstract}
Total hydroxyl radical $(\mathrm{OH})$ reactivity was measured at the PROPHET (Program for Research on Oxidants: PHotochemistry, Emissions, and Transport) forested field site in northern Michigan during the 2009 Community Atmosphere-Biosphere INteraction EXperiment (CABINEX). OH reactivity measurements were made with a turbulent-flow reactor instrument at three heights from the forest floor above $(21$ and $31 \mathrm{~m})$ and below $(6 \mathrm{~m})$ the canopy at three different time periods during the CABINEX campaign. In addition to total $\mathrm{OH}$ reactivity measurements, collocated measurements of volatile organic compounds (VOCs), inorganic species, and ambient temperature were made at the different heights. These ancillary measurements were used to calculate the total $\mathrm{OH}$ reactivity, which was then compared to the measured values. Discrepancies between the measured and calculated $\mathrm{OH}$ reactivity, on the order of $1-24 \mathrm{~s}^{-1}$, were observed during the daytime above the canopy at the 21 and $31 \mathrm{~m}$ heights, as previously reported for this site. The measured $\mathrm{OH}$ reactivity below the canopy during the daytime was generally lower than that observed above the canopy. Closer analysis of the measurements of $\mathrm{OH}$ reactivity and trace gases suggests that the missing $\mathrm{OH}$ reactivity could
\end{abstract}

come from oxidation products of VOCs. These results suggest that additional unmeasured trace gases, likely oxidation products, are needed to fully account for the $\mathrm{OH}$ reactivity measured during CABINEX.

\section{Introduction}

The hydroxyl radical $(\mathrm{OH})$ is an important oxidant in the troposphere. $\mathrm{OH}$ controls the chemical lifetimes of many important atmospheric trace gases (Ehhalt, 1998) and is also involved in the formation of tropospheric ozone and secondary organic aerosols. Because of the key role that $\mathrm{OH}$ plays in tropospheric chemistry, an accurate understanding of $\mathrm{OH}$ sources and sinks is important. Due to its high reactivity, there are numerous sinks of $\mathrm{OH}$ in the atmosphere. Among the most important are nitrogen oxides and volatile organic compounds (VOCs). However, of the hundreds of possible VOCs within the atmosphere, many still elude detection by traditional VOC measurement techniques (Goldstein and Galbally, 2007). Thus, a complete characterization of all the individual $\mathrm{OH}$ sinks is a daunting task. One way to 
characterize $\mathrm{OH}$ sinks without the need for measurements of their concentrations is to directly measure the total $\mathrm{OH}$ loss rate due to chemical reactions through measurements of the total $\mathrm{OH}$ reactivity.

The $\mathrm{OH}$ reactivity $\left(k_{\mathrm{X}}\right)$ is defined for a chemical species $\mathrm{X}$ as the product of the second-order rate constant (or, for termolecular reactions, the bimolecular rate constant calculated at the working pressure) for the reaction of $\mathrm{X}$ with $\mathrm{OH}$ $\left(k_{\mathrm{X}, \mathrm{OH}}\right)$ and the concentration of $\mathrm{X}$ :

$k_{\mathrm{X}}=k_{\mathrm{X}, \mathrm{OH}}[\mathrm{X}]$.

The total $\mathrm{OH}$ reactivity $k_{\mathrm{OH}}$, which is the inverse of the $\mathrm{OH}$ lifetime, can be derived by summing the $\mathrm{OH}$ reactivity for each chemical species $\mathrm{X}_{i}$ :

$k_{\mathrm{OH}}=\sum_{i} k_{\mathrm{X}_{i}, \mathrm{OH}}\left[\mathrm{X}_{i}\right]$

Instruments to measure ambient total $\mathrm{OH}$ reactivity have been recently developed and deployed in several field campaigns (Lou et al., 2010; Dolgorouky et al., 2012; Nölscher et al., 2012; Sinha et al., 2012). These instruments employ one of three methods, all of which measure the $\mathrm{OH}$ reactivity by mixing ambient air with a large amount of $\mathrm{OH}$ in a sampling reactor and monitoring the change in the concentration of $\mathrm{OH}$ or a tracer molecule. The first method, known as the total $\mathrm{OH}$ loss rate method (TOHLM) (Kovacs and Brune, 2001; Ingham et al., 2009), uses a flow tube reactor with a movable $\mathrm{OH}$ injector coupled to a laser-induced fluorescence detection cell (fluorescence assay with gas expansion, FAGE). A second method, the dual-laser pump-probe method (Sadanaga et al., 2004b), employs one laser for $\mathrm{OH}$ generation at $266 \mathrm{~nm}$ from the photolysis of ambient $\mathrm{O}_{3}$ in the sampling reactor and a laser-induced fluorescence detection cell (FAGE) to probe $\mathrm{OH}$. Both methods rely on the direct detection of $\mathrm{OH}$ to measure the first-order $\mathrm{OH}$ loss rate. The third method, known as the comparative reactivity method (CRM) (Sinha et al., 2008), is an indirect method in which a tracer molecule is detected instead of $\mathrm{OH}$ to determine the ambient $\mathrm{OH}$ loss rate.

Direct measurements of total $\mathrm{OH}$ reactivity from any one of these techniques can be compared to values calculated via Eq. (2) from measured concentrations of known $\mathrm{OH}$ sinks to assess whether unmeasured trace gases are important unaccounted $\mathrm{OH}$ sinks. The difference between the measured and calculated total $\mathrm{OH}$ reactivity is referred to as the "missing" $\mathrm{OH}$ reactivity and represents the loss of $\mathrm{OH}$ from unmeasured sinks.

Missing $\mathrm{OH}$ reactivity analyses have been conducted for several urban and forested areas. The agreement between measured and calculated total $\mathrm{OH}$ reactivity in urban areas has generally been good, with missing $\mathrm{OH}$ reactivity of less than $3 \mathrm{~s}^{-1}$ (5-10\% of the measured total $\mathrm{OH}$ reactivity), well within the combined uncertainties of the $\mathrm{OH}$ reactivity measurements and the $\mathrm{OH}$ reactivity calculations (Ren et al., 2003a; Di Carlo et al., 2004; Mao et al., 2010). However, some missing $\mathrm{OH}$ reactivity on the order of $5-30 \mathrm{~s}^{-1}$ (10-50\% of the total) has been seen sometimes in Nashville (Kovacs et al., 2003), New York City (Ren et al., 2006a), and Tokyo (Chatani et al., 2009; Sadanaga et al., 2004a; Yoshino et al., 2006).

In contrast, the agreement between calculated and measured total $\mathrm{OH}$ reactivity has been poorer in forested environments (Table 1). Previous measurements of $\mathrm{OH}$ reactivity made at the PROPHET (Program for Research on Oxidants: PHotochemistry, Emissions, and Transport) site in northern Michigan found missing $\mathrm{OH}$ reactivity values between 1 and $4 \mathrm{~s}^{-1}$ (33-50\% of the total) that exhibited a clear dependence on temperature (Di Carlo et al., 2004). OH reactivity measurements in a coniferous forest in California also found significant missing $\mathrm{OH}$ reactivity that also displayed a temperature dependence, although the absolute values were higher (2.5-10 s ${ }^{-1}, 30-40 \%$ of the total) (Mao et al., 2012). Even higher missing $\mathrm{OH}$ reactivity $\left(36 \mathrm{~s}^{-1}, 68 \%\right.$ of the total) was measured in a rainforest in Suriname in 2005 (Sinha et al., 2008). The magnitude of missing $\mathrm{OH}$ reactivity from a boreal forest in Finland was less, being only $4.6 \mathrm{~s}^{-1}$ on average, but this accounted for $50 \%$ of the total $\mathrm{OH}$ reactivity in this environment (Sinha et al., 2010). Similar results were obtained at the same site in 2010 , with $8.9 \mathrm{~s}^{-1}$ of missing reactivity on average comprising $77 \%$ of the total $\mathrm{OH}$ reactivity (Nölscher et al., 2012).

Of all the studies of $\mathrm{OH}$ reactivity conducted in forested environments (summarized in Table 1), only one study does not report significant missing $\mathrm{OH}$ reactivity (Ren et al., 2006b). This study was conducted in a deciduous forest in eastern New York State, which is influenced by urban air masses. It is unclear why no significant missing $\mathrm{OH}$ reactivity was observed at this site, although the median contribution of isoprene to $\mathrm{OH}$ reactivity was only $14 \%$ (Ren et al., 2006b). In other campaigns conducted in forested areas, the measured $\mathrm{OH}$ reactivity has been at least $50 \%$ higher than the $\mathrm{OH}$ reactivity calculated from measured trace species. This missing reactivity has been attributed to undetected emissions of highly reactive biogenic VOCs (BVOCs; Di Carlo et al., 2004; Sinha et al., 2010), unmeasured VOC oxidation products (Edwards et al., 2013; Lou et al., 2010; Mao et al., 2012), or combinations of these two (Nölscher et al., 2012).

Most of the $\mathrm{OH}$ reactivity measurements to date within forested environments have been made above the forest canopy (see Table 1). As locally emitted VOCs and their oxidation products, trace gases carried by transport, and solar radiation are all present above the canopy, this environment is expected to be the most chemically active within the forest. However, Holzinger et al. (2005) have observed VOC oxidation products both above and below a forest canopy, indicating that the below-canopy $\mathrm{OH}$ reactivity may also provide useful information to investigate potential sources of missing $\mathrm{OH}$ reactivity. One-dimensional modeling by Mogensen 
Table 1. Summary of total $\mathrm{OH}$ reactivity measurements in forested environments.

\begin{tabular}{|c|c|c|c|c|c|c|c|c|}
\hline Campaign & Site & Dates & Forest type & $z_{\text {meas }} / z_{c}^{\mathrm{a}}$ & $\mathrm{MR}^{\mathrm{b}}$ & $k_{\mathrm{OH}}\left(\mathrm{s}^{-1}\right)^{\mathrm{c}}$ & Tech. $^{d}$ & Reference \\
\hline PROPHET 2000 & Michigan, USA & Jul-Aug 2000 & Mixed deciduous & 1.5 & $\sim 1.5$ & $1-12^{\mathrm{e}}$ & $\mathrm{T}$ & Di Carlo et al. (2004) \\
\hline PMTACS & Whiteface Mountain, NY, USA & Jul-Aug 2002 & Mixed deciduous & f & $\sim 1$ & $3-12$ & $\mathrm{~T}$ & Ren et al. (2006b) \\
\hline$(\mathrm{N} / \mathrm{A})$ & Brownsberg, Suriname & Oct 2005 & Rainforest & 0.88 & $\sim 3.5$ & $30-70$ & $\mathrm{C}$ & Sinha et al. (2008) \\
\hline OP-3 & Borneo, Malaysia & Apr-May 2008 & Rainforest & $\mathrm{g}$ & $\sim 3^{\mathrm{h}}$ & $5-80$ & $\mathrm{~T}$ & Edwards et al. (2013) \\
\hline SMEAR/ BFORM & Hyytiälä, Finland & Aug 2008 & Boreal & 0.86 & $\sim 3-4^{\mathrm{i}}$ & $3-30$ & $\mathrm{C}$ & Sinha et al. (2010) \\
\hline BEARPEX 2009 & California, USA & Jun-Jul 2009 & Coniferous & $1-1.7^{\mathrm{j}}$ & $\sim 1.5$ & $8-25^{\mathrm{e}}$ & $\mathrm{T}$ & Mao et al. (2012) \\
\hline \multirow[t]{2}{*}{ HUMPPA-COPEC 2010} & Hyytiälä, Finland & Jul-Aug 2010 & Boreal & $0.87^{\mathrm{k}}$ & 1 & $3-76$ & $\mathrm{C}$ & Nölscher et al. (2012) \\
\hline & & & & $1.17^{\mathrm{k}}$ & $5.22^{\mathrm{m}}$ & $3-60$ & $\mathrm{C}$ & \\
\hline \multirow[t]{3}{*}{ CABINEX } & Michigan, USA & Jul-Aug 2009 & Mixed deciduous & $0.32^{\mathrm{p}}$ & $2.26^{\mathrm{q}}$ & $1-39$ & $\mathrm{~T}$ & This work \\
\hline & & & & $1.1^{\mathrm{p}}$ & $2.07^{\mathrm{q}}$ & $1-39$ & $\mathrm{~T}$ & \\
\hline & & & & $1.63^{\mathrm{p}}$ & $2.34 \mathrm{q}$ & $1-42$ & $\mathrm{~T}$ & \\
\hline
\end{tabular}

et al. (2011) shows that ambient $\mathrm{OH}$ reactivity can vary with height in a forest environment. These observations motivate further measurements both within and below the forest canopy.

The Community Atmosphere-Biosphere INteraction EXperiment (CABINEX) campaign during the summer of 2009 provided an opportunity to measure $\mathrm{OH}$ reactivity at multiple heights within a forest canopy where previous measurements from this site highlighted significant missing $\mathrm{OH}$ reactivity above the canopy at a height of $29 \mathrm{~m}$ (Di Carlo et al., 2004). This paper presents measurements of total $\mathrm{OH}$ reactivity at three heights $(6,21$, and $31 \mathrm{~m})$ above the floor of a mixed deciduous forest. The measurements made below the canopy at $6 \mathrm{~m}$ and above the canopy at 21 and $31 \mathrm{~m}$ have been analyzed and compared to $\mathrm{OH}$ reactivity values calculated from collocated measurements of VOCs and inorganic trace species to confirm whether missing $\mathrm{OH}$ reactivity is observed above the canopy and to gain insights into processes that could lead to some missing $\mathrm{OH}$ reactivity at this site.

\section{Experimental}

\subsection{Instrument description}

The total $\mathrm{OH}$ reactivity instrument used for these measurements is based on the total OH loss rate method (TOHLM) (Kovacs and Brune, 2001), which itself is an adaptation of the flow-discharge technique used in kinetic studies (Seeley et al., 1993). The Indiana University instrument (IU-TOHLM) consists of three major components (Fig. 1): a movable $\mathrm{OH}$ radical source, a flow tube reactor, and an $\mathrm{OH}$ radical detection system that is connected to the flow tube reactor through an adapter block.

The flow tube reactor consists of a $5 \mathrm{~cm}$-i.d. (inner diameter) glass tube that is $75 \mathrm{~cm}$ in length with several $1.2 \mathrm{~cm}$-o.d. (outer diameter) ports (at $25 \mathrm{~cm}$ intervals) along the length of the tube. At the upstream end of the reactor, there are two $5 \mathrm{~cm}$-o.d. intake arms perpendicular to each other. Ambient air is introduced through the intake arm perpendicular to the main axis of the reactor. To determine the loss rate of $\mathrm{OH}$ due to wall reactions in the flow tube $\left(k_{b}\right)$, high-purity nitrogen from a liquid nitrogen dewar (Indiana Oxygen, industrial grade for laboratory measurements; Airgas, 99.999\% purity for field measurements) is introduced through an intake arm perpendicular to the main axis of the reactor (Fig. 1). The $\mathrm{OH}$ radical source injector is inserted along the main axis of the reactor (Fig. 1). The gas velocity is measured near the exit of the flow tube reactor with a Pitot-static tube (Dwyer Instruments 167-6) connected to a 0-1.8 torr differential pressure gauge (Omega Instruments PX654-015DV). The end of the Pitot tube is placed within the reactor facing the opposite direction of the main flow, approximately $1 \mathrm{~cm}$ away from the reactor wall at a distance of $4.5 \mathrm{~cm}$ upstream of the $\mathrm{OH}$ detection system. This places the Pitot tube within the turbulent core region of the reactor. Since the $\mathrm{OH}$ detection axis, due to its orientation relative to the flow tube, samples preferentially from the turbulent core region, the flow velocity should be measured in this region for accurate kinetic measurements (Seeley et al., 1993). To confirm the accuracy of flow velocity measurements, the Pitot tube was collocated with a portable hot-wire anemometer (Testo v 405), and standard flows of nitrogen (40-200 $\mathrm{L} \mathrm{min}^{-1}$ ) were passed through the flow tube. The flow velocity measurements made using the anemometer and the Pitot tube were within $10 \%$ of each other. To measure the temperature of the air inside the flow tube, a thermocouple was placed inside the flow tube within a port closest to the exit, approximately $12 \mathrm{~cm}$ from the exit of the flow tube.

The $\mathrm{OH}$ radical source injector consists of a mercury pen lamp (UVP Pen-Ray) housed in a 2 m-long, $1.25 \mathrm{~cm}$-o.d. stainless steel tube. The top of the mercury pen lamp is positioned approximately $1 \mathrm{~cm}$ upstream of the exit of the injector. On the downstream end of the injector, there is an aluminum cap with small holes drilled concentrically with an approximately $60^{\circ}$ angle of coverage to promote the mixing of $\mathrm{OH}$ radicals with the main flow. In addition to enhancing mixing of $\mathrm{OH}$ radicals within the reactor, this cap 


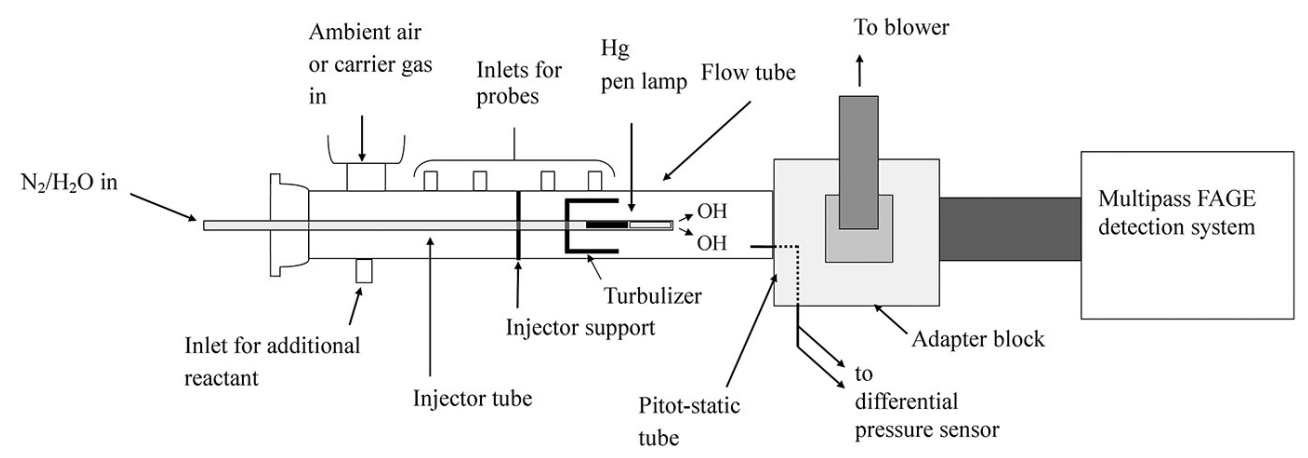

Fig. 1. Diagram of the IU-TOHLM instrument.

also minimizes the dispersion of ultraviolet radiation into the reactor, where some ambient trace species could be photolyzed. A turbulizer, made of Teflon and consisting of four $1 \mathrm{~cm}$-wide fins placed at $90^{\circ}$ angles along the circumference of the flow tube, is attached to the injector $10 \mathrm{~cm}$ upstream of the cap to help promote mixing and to help establish turbulent flow conditions (Seeley et al., 1993).

To generate $\mathrm{OH}$ radicals, a $5-10 \mathrm{~L} \mathrm{~min}^{-1}$ flow of nitrogen is bubbled through high-purity water (EMD Chemicals), producing a humid flow of carrier gas. The water vapor is then photolyzed by the $185 \mathrm{~nm}$ emission from the mercury lamp, producing approximately equal concentrations of $\mathrm{OH}$ and $\mathrm{H}$ atoms.

$\mathrm{H}_{2} \mathrm{O}+h v(185 \mathrm{~nm}) \longrightarrow \mathrm{H} \cdot+\mathrm{OH} \cdot$

The $\mathrm{H}$ atoms produced from reaction $\mathrm{R} 1$ can then react rapidly with molecular oxygen present as an impurity in the carrier gas to produce $\mathrm{HO}_{2}$ radicals. Any unreacted $\mathrm{H}$ atoms leaving the injector would react with ambient $\mathrm{O}_{2}$ to form $\mathrm{HO}_{2}$ radicals due to the large excess of oxygen in air compared to trace gases.

$\mathrm{H} \bullet+\mathrm{O}_{2}+\mathrm{M} \longrightarrow \mathrm{HO}_{2} \cdot+\mathrm{M}$

Under field measurement conditions, it was determined through calibration of the $\mathrm{OH}$ detection axis (Dusanter et al., 2008) that the initial concentration of $\mathrm{OH}$ radicals in the reactor after mixing was on the order of 1 to $5 \times 10^{9} \mathrm{~cm}^{-3}$, which is approximately 3 to 4 orders of magnitude above typical ambient $\mathrm{OH}$ concentrations.

Kovacs and Brune (2001) demonstrated that $\mathrm{HO}_{2}$ radicals produced in the reactor via Reaction (R2) can regenerate $\mathrm{OH}$ at ambient NO mixing ratios above $1 \mathrm{ppbv}$. This secondary source of $\mathrm{OH}$ increases the $\mathrm{OH}$ concentration in the reactor, causing the $\mathrm{OH}$ decay to appear slower than it actually is, thus yielding a lower value of $\mathrm{OH}$ reactivity. These authors proposed a correction procedure for environments where NO is present at mixing ratios greater than $1 \mathrm{ppbv}$ (Ren et al., 2003b), based on concomitant measurements of $\mathrm{HO}_{2}, \mathrm{OH}$ and $\mathrm{NO}$ in the reactor. However, since the ambient daytime mixing ratios of NO during CABINEX were generally below
70 pptv with an average morning peak around 150 pptv, this correction was not necessary.

The $\mathrm{OH}$ detection system employs the FAGE technique for $\mathrm{OH}$ measurements, and is described in detail by Dusanter et al. (2009). Briefly, air from the reactor is sampled through a $1 \mathrm{~mm}$ pinhole and is expanded into a low-pressure cell held between 5 and 10 torr. This range of pressures is dependent on the orifice used with the FAGE inlet. With the orifice and pumping setup used during CABINEX, the pressure in the FAGE cell was $10.8 \pm 0.5$ torr. A tunable dye laser (Lambda Physik ScanMate 1) pumped by a Nd-YAG laser (Spectra Physics Navigator) operating at a pulse repetition rate of $5 \mathrm{kHz}$ is used to produce coherent light at a wavelength of $616 \mathrm{~nm}$. The frequency of this output is doubled with a BBO doubling crystal to produce radiation near $308 \mathrm{~nm}$. A small fraction of the $308 \mathrm{~nm}$ light is sent to a reference cell, where a high concentration of $\mathrm{OH}$ is produced by thermal decomposition of water vapor. The resulting fluorescence signal is then detected by a photomultiplier tube and is used to determine when the wavelength of the laser is tuned in resonance with the $A^{2} \Sigma^{+}\left(v^{\prime}=0\right) \leftarrow \mathrm{X}^{2} \Pi\left(v^{\prime \prime}=0\right)$ electronic transition of $\mathrm{OH}$. Approximately $38 \%$ of the output from the laser is transmitted to the detection cell through a $2 \mathrm{~m}$ optical fiber (ThorLabs FG-200-UCR). The laser light then enters a multipass White cell and is reflected 20 times across the airstream. The resulting fluorescence is detected by a gated microchannel plate detector (Hamamatsu R5916U-52), and the signal is processed by a preamplifier (Advanced Instruments F100T) before being monitored by a photon counter (Stanford Research SRS 400).

A regenerative blower (Spencer VB001) connected to the adapter block pulls ambient air through the instrument at a flow rate of $175-400 \mathrm{~L} \mathrm{~min}^{-1}\left(v \approx 150-350 \mathrm{~cm} \mathrm{~s}^{-1}\right)$, establishing turbulent flow conditions within the reactor with Reynolds numbers between 5000 and 11000 . Turbulent flow has several advantages over laminar flow conditions for measurements of reaction kinetics. In fully developed turbulent flows, exchange between the laminar sublayer at the walls of the reactor and the turbulent core is minimal (Seeley et al., 1993). This minimizes losses of VOCs and $\mathrm{OH}$ to the reactor 
walls. Turbulent flow also promotes the mixing of VOCs and $\mathrm{OH}$, which reduces the possibility of reactant segregation. To verify that the flow is turbulent within the reactor, flow velocity profiles were measured at the exit of the reactor with the Pitot tube. The flow velocity profile was measured approximately $2 \mathrm{~cm}$ upstream of the exit of the flow tube. Measurements of flow velocity were made at increments of $2 \mathrm{~mm}$ along the internal diameter of the flow tube. The flow velocity was uniform throughout the inner diameter of the flow tube for carrier gas flow rates above $100 \mathrm{~L} \mathrm{~min}^{-1}$, with a $10 \%$ higher flow velocity at the center and sharp dropoffs near the wall of the flow tube. This profile matches the characteristics of turbulent flow as described by Seeley et al. (1993).

For ambient measurements, air is sampled through an $8.1 \mathrm{~cm}$-i.d. hose constructed of perfluoroalkoxy (PFA) polymer film (thickness $0.13 \mathrm{~mm}$ ) and attached to the ambient air intake. Different lengths of inlet tubing were used to sample at the various heights. A $14 \mathrm{~m}$ inlet was used for the $6 \mathrm{~m}$ measurements, while a $36 \mathrm{~m}$ inlet was used for the 21 and $31 \mathrm{~m}$ heights. The 14 and $36 \mathrm{~m}$ lengths of tubing resulted in residence times of air samples in the inlets of approximately 20 and $30 \mathrm{~s}$, respectively, at the sampling flow rates used with each inlet during field measurements. To ensure that the inlet did not have an effect on the total $\mathrm{OH}$ reactivity measurements, various lengths of tubing $(6-40 \mathrm{~m})$ were attached to the flow tube reactor during laboratory experiments to change the residence time of air samples in the inlet (10-75 s) while measuring ambient $\mathrm{OH}$ reactivity at the same location. No statistically significant difference in $\mathrm{OH}$ reactivity was seen in these tests. A similar test was also performed in the field. For the CABINEX campaign, an additional inlet section ( $7 \mathrm{~m}$ long) was attached to a sampling inlet of $6.7 \mathrm{~m}$, doubling the inlet length. The added section of inlet was alternately attached and removed every $30 \mathrm{~min}$. The difference in reactivity between the $13.7 \mathrm{~m}$ inlet and the $6.7 \mathrm{~m}$ inlet was $0.32 \pm 0.5 \mathrm{~s}^{-1}(n=9)$.

An automated linear motion system controls the movement of the $\mathrm{OH}$ injector. The injector is moved over a $37.5 \mathrm{~cm}$ path which starts $5 \mathrm{~cm}$ upstream of the FAGE detection inlet. The $\mathrm{OH}$ fluorescence signal is measured continuously (at a frequency of approximately $2 \mathrm{~Hz}$ ) over the path of the injector in both the forward and reverse directions (Fig. 2). For the IU-TOHLM instrument, each $\mathrm{OH}$ decay measurement takes approximately $2.5 \mathrm{~min}$ to complete.

Under pseudo-first-order conditions (i.e., $[\mathrm{OH}] \ll[\mathrm{X}]$ ), the concentration of $\mathrm{OH}$ over time can be expressed as a firstorder exponential decay:

$[\mathrm{OH}]_{t}=[\mathrm{OH}]_{0} \exp \left(-\left(k_{\mathrm{OH}}+k_{b}\right) t\right)$.

Solving Eq. (3) for the $\mathrm{OH}$ reactivity $k_{\mathrm{OH}}$ results in Eq. (4),

$k_{\mathrm{OH}}=\frac{-\Delta(\ln [\mathrm{OH}])}{\Delta t}-k_{b}$,

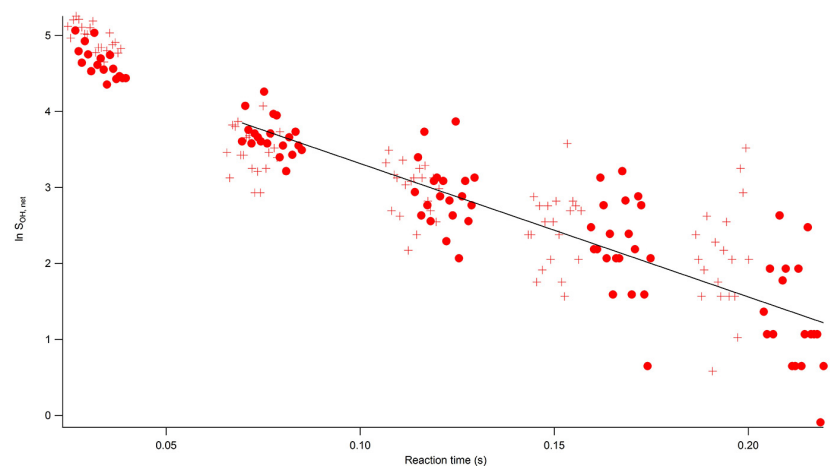

Fig. 2. Two subsequent $\mathrm{OH}$ decays from $\mathrm{CABINEX}$, one measured with the injector traveling in the forward direction (crosses) and one measured with the injector traveling in the reverse direction (circles) on 10 July 2009. The solid line shows a linear fit yielding a value of $\mathrm{OH}$ reactivity of $16.4 \mathrm{~s}^{-1}$.

where $k_{b}$ represents the $\mathrm{OH}$ loss rate due to wall reactions that is measured by flowing pure $\mathrm{N}_{2}$ in the reactor. Note that dilution of $\mathrm{OH}$ in the core flow at the exit of the injector is also accounted for in $k_{b}$. Measurements of $k_{b}$ were conducted both in the laboratory and in the field using nitrogen gas output from a liquid nitrogen dewar. Tests in the field were conducted on four separate days (see below). To test the effects of impurities from the carrier $\mathrm{N}_{2}$ in the $\mathrm{OH}$ source on $k_{b}$, measurements of $k_{b}$ were performed alternately with nitrogen from an industrial-grade $\mathrm{N}_{2}$ dewar (Indiana Oxygen) and VOC-free nitrogen (purity of $99.9995 \%$, Matheson). The average difference between the $k_{b}$ values from these two sources was $0.24 \mathrm{~s}^{-1}$, which corresponds to approximately $7 \%$ of the $k_{b}$ measured in these tests.

Measurements of $k_{b}$ conducted in the laboratory exhibited similar relative variation to those conducted in the field. The day-to-day variability for the laboratory tests was approximately $10 \%$ (from $1 \sigma$ of $0.6 \mathrm{~s}^{-1}$ ), and the variation among the four field tests was approximately $8 \%$ (from $1 \sigma$ of $0.28 \mathrm{~s}^{-1}$ ). The average value of $k_{b}$ for the field and laboratory tests was $3.6 \pm 0.2 \mathrm{~s}^{-1}(n=39)$ for total flow rates between 130 and $200 \mathrm{~L} \mathrm{~min}^{-1}$, where the uncertainty represents one standard deviation of the average value. This value of $k_{b}$ measured with the IU-TOHLM instrument is comparable to those reported previously for similar instruments (Kovacs and Brune, 2001; Mao et al., 2009; Ingham et al., 2009). The laboratory tests suggest that $k_{b}$ may decrease with increasing flow rates in the reactor, and may be $1-2 \mathrm{~s}^{-1}$ lower for flow rates higher than $200 \mathrm{~L} \mathrm{~min}^{-1}$. For the belowcanopy measurements the average flow rate was approximately $220 \mathrm{~L} \mathrm{~min}^{-1}$, while for the above-canopy measurements, the average flow rate was approximately $350 \mathrm{~L} \mathrm{~min}^{-1}$. Unfortunately, measurements of $k_{b}$ at flow rates greater than $200 \mathrm{~L} \mathrm{~min}^{-1}$ were not made in the field during CABINEX. As a result, the average value of $k_{b}$ measured in these tests likely represents an upper limit to the background reactivity 
for the above-canopy measurements, leading to a lower limit for the overall reactivity measured at 21 and $31 \mathrm{~m}$.

Since the $\mathrm{OH}$ fluorescence signal is proportional to $\mathrm{OH}$ concentration, the net $\mathrm{OH}$ signal $S_{\mathrm{OH}}$ (the difference of the on-resonance and off-resonance $\mathrm{OH}$ fluorescence signals) can be substituted for $[\mathrm{OH}]$ in Eq. (4). Thus, the $\mathrm{OH}$ reactivity can be determined from the slope of a plot of the natural logarithm of $S_{\mathrm{OH}}$ as a function of reaction time (Fig. 2). Since the $\mathrm{OH}$ generated within the injector is still not completely mixed with the reactants in the reactor at short reaction times $(<50-60 \mathrm{~ms})$, it is difficult to separate the $\mathrm{OH}$ loss due to dilution from the $\mathrm{OH}$ loss due to chemical reaction (Ingham et al., 2009). For this reason, analysis of the $\mathrm{OH}$ decays was started at a reaction time of $60 \mathrm{~ms}$, when the injector was approximately $12 \mathrm{~cm}$ upstream of the FAGE inlet. However, this places an upper limit of $45 \mathrm{~s}^{-1}$ on the $\mathrm{OH}$ reactivity measurements with the IU-TOHLM instrument.

The accuracy and precision of the IU-TOHLM measurements were evaluated during laboratory experiments by measurements of the $\mathrm{OH}$ reactivity of four standard mixtures (propane, butane, tetramethylethylene (TME), and isoprene). These are representative of compounds that are present in ambient air and have well-established rate constant values spanning two orders of magnitude $\left(10^{-12}\right.$ $10^{-10} \mathrm{~cm}^{3}$ molecule ${ }^{-1} \mathrm{~s}^{-1}$ ) (Atkinson et al., 1995, 2006; Atkinson, 1997, 2003). A correlation plot of the measured and calculated $\mathrm{OH}$ reactivity (Fig. 3) shows that measurements are on average $38 \%$ lower than calculated values when the measured velocity of the turbulent core is used to determine the reaction time. Similar discrepancies are observed for all the test compounds and suggest either an incomplete mixing between the reactants or a systematic underestimation of the reaction time. In addition, subsequent tests with trans-2-butene and propane showed similar behavior. Measured ambient $\mathrm{OH}$ reactivity values are scaled up by a factor determined from the fit shown in Fig. 3 to account for the average difference observed in these laboratory experiments. Given the similar behavior for all the test compounds, whose rate constants for reaction with $\mathrm{OH}$ span two orders of magnitude, and the linearity of the measured $\mathrm{OH}$ reactivity as a function of the calculated $\mathrm{OH}$ reactivity, it appears that this discrepancy does not vary with $\mathrm{OH}$ reactivity up to $35 \mathrm{~s}^{-1}$. We therefore assume a linear scaling factor to account for the discrepancy.

The limit of detection $(1 \sigma)$, determined from measurements of $k_{b}$ described above, is $0.7 \mathrm{~s}^{-1}$ under field conditions for a $10 \mathrm{~min}$ average. Measurements performed at multiple $\mathrm{OH}$ reactivity values indicate that the IU-TOHLM instrument can measure $\mathrm{OH}$ reactivity up to $45 \mathrm{~s}^{-1}$ with a $1 \sigma$ precision of $\left(1.2 \mathrm{~s}^{-1}+4 \%\right.$ of the measured value $)$ for a $10 \mathrm{~min}$ average.

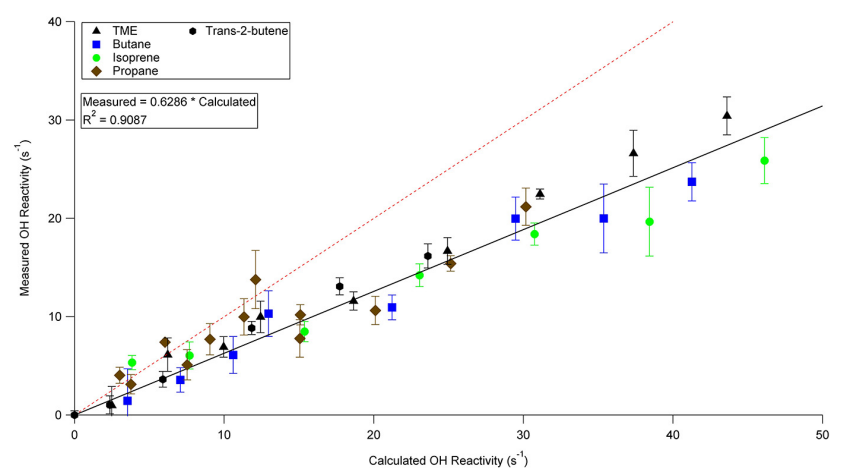

Fig. 3. Summary of laboratory characterizations of IU-TOHLM instrument. The dashed line represents the $1: 1$ line; the solid line is a linear fit of the data set represented by the solid markers. Error bars represent $1 \sigma$ standard deviation of the average values.

\subsection{Field measurements during CABINEX}

The CABINEX field campaign was conducted from 1 July to 8 August 2009 at the PROPHET field site at the University of Michigan Biological Station in northern Michigan (Carroll et al., 2001). This site is located within a mixed deciduous forest with an average canopy height of $20 \mathrm{~m}$. A previous study of the biomass within the area surrounding the site found an average of $156 \pm 11 \mathrm{~g} \mathrm{~m}^{-2}$ of isoprene-emitting biomass, $90 \%$ of which was attributed to aspen (Westberg, 2001).

The CABINEX campaign consisted of two phases; the first (1-20 July) focused on measurements below the forest canopy ( $6 \mathrm{~m}$ above ground level), and the second (21 July-8 August) focused on measurements above the forest canopy ( 21 and $31 \mathrm{~m}$ above ground level). Further details on the CABINEX campaign can be found in companion papers (Bryan et al., 2012; Griffith et al., 2013). Due to the limited instrumentation and variation in sampling schemes, the availability of collocated measurements varies among the different heights. Measurement techniques and their associated uncertainties are given in Table 2.

VOCs were measured with a proton transfer reaction mass spectrometer (PTR-MS) from Washington State University modified to incorporate dehumidified sampling for increased sensitivity toward formaldehyde (Jobson and McCoskey, 2010). The PTR-MS measurements include isoprene, the sum of methyl vinyl ketone and methacrolein (MVK + MACR), total monoterpenes, formaldehyde (HCHO), acetaldehyde, methanol, methyl hydroperoxide, acetone, methyl ethyl ketone, toluene, benzene, and the sum of C2-alkylbenzenes. The VOC measurements were alternated between the three heights $(6,21$, and $31 \mathrm{~m})$ at $10 \mathrm{~min}$ intervals.

Ambient temperature was measured with temperature probes (R. M. Young) placed at a height of $6 \mathrm{~m}$ on a trailer deployed by Washington State University and on the PROPHET tower at heights of 20.4 and $31.2 \mathrm{~m}$. Ozone was 
Table 2. Summary of supporting measurements from CABINEX used for $\mathrm{OH}$ reactivity calculations.

\begin{tabular}{|c|c|c|c|}
\hline Measurement & Technique & $\begin{array}{l}\text { Time resolution } \\
(\mathrm{min}) / \text { uncertainty } \\
(\%, 1 \sigma) / \mathrm{LOD}(\mathrm{ppbv})\end{array}$ & Institution \\
\hline 12 VOCs: & $\begin{array}{l}\text { Proton transfer } \\
\text { reaction mass } \\
\text { spectrometry } \\
\text { (PTR-MS) }\end{array}$ & & $\begin{array}{l}\text { Washington State } \\
\text { University }\end{array}$ \\
\hline Isoprene & & $1 / 5 / 0.05$ & \\
\hline Methyl vinyl ketone & & & \\
\hline+ methacrolein & & $1 / 5 / 0.07$ & \\
\hline Formaldehyde & & $1 / 10 / 0.14$ & \\
\hline Acetaldehyde & & $1 / 5 / 0.09$ & \\
\hline Acetone & & $1 / 5 / 0.12$ & \\
\hline Methyl ethyl ketone & & $1 / 5 / 0.12$ & \\
\hline Methanol & & $1 / 5 / 0.12$ & \\
\hline Benzene & & $1 / 5 / 0.04$ & \\
\hline Toluene & & $1 / 5 / 0.04$ & \\
\hline Methyl peroxide & & $1 /-^{*} / 0.05$ & \\
\hline Total monoterpenes & & $1 / 5 / 0.07$ & \\
\hline Ozone & $\begin{array}{l}\text { UV absorption } \\
\text { (Teledyne API } \\
\text { 400E/Thermo } \\
\text { Electron) }\end{array}$ & $1 / 10 / 1$ & $\begin{array}{l}\text { Indiana Univ./Univ. } \\
\text { of Michigan }\end{array}$ \\
\hline $\mathrm{NO}_{2}$ & $\begin{array}{l}\text { Chemiluminescence } \\
\text { (Air Quality Design) }\end{array}$ & $1 / 12 / 0.002$ & $\begin{array}{l}\text { Washington State } \\
\text { University }\end{array}$ \\
\hline $\mathrm{CO}$ & $\begin{array}{l}\text { IR absorption } \\
\text { (Thermo Electron 48C) }\end{array}$ & $1 / 6 / 40$ & $\begin{array}{l}\text { University of } \\
\text { Michigan }\end{array}$ \\
\hline \multirow[t]{2}{*}{$\begin{array}{l}\text { Meteorological data: } \\
\text { temperature, } \\
\text { pressure }\end{array}$} & & $1 /-/-$ & $\begin{array}{l}\text { Washington State } \\
\text { Univ. }(6 \mathrm{~m})\end{array}$ \\
\hline & & $1 /-/-$ & $\begin{array}{l}\text { University of } \\
\text { Michigan }(21 \mathrm{~m}, 31 \mathrm{~m})\end{array}$ \\
\hline$J\left(\mathrm{NO}_{2}\right)$ & SAFS & $1 / 30 /-$ & University of Houston \\
\hline
\end{tabular}

* Uncertainty for methyl peroxide not yet quantified; refer to Jobson and McCoskey (2010) for further details.

measured by UV absorption using a Teledyne Model 400E. $\mathrm{CO}$ was measured by IR absorption using a Thermo Electron $48 \mathrm{C}$ by the University of Michigan in addition to ozone measurements using a Thermo Electron 49C instrument (Carroll et al., 2001). Nitrogen oxides $\left(\mathrm{NO}_{\mathrm{x}}=\mathrm{NO}+\mathrm{NO}_{2}\right)$ were measured by Washington State University using an instrument based on chemiluminescence of $\mathrm{NO}$ and equipped with a blue light photolytic converter for $\mathrm{NO}_{2}$ measurements (Air Quality Design). The $\mathrm{NO}_{\mathrm{x}}$ measurements were alternated between the 6,21 , and $31 \mathrm{~m}$ heights in a similar manner to the VOC measurements. Photolysis frequencies for $\mathrm{NO}_{2}$ were calculated from measurements made by the University of Houston with a scanning actinic flux spectroradiometer (SAFS) (Shetter et al., 2003) located at $32.6 \mathrm{~m}$.

Measurements of total $\mathrm{OH}$ reactivity were made at three locations: below the forest canopy at a height of $6 \mathrm{~m}$, approximately $1 \mathrm{~m}$ above the top of the canopy at a height of $21 \mathrm{~m}$, and above the canopy at a height of $31 \mathrm{~m}$. Approximately
17 days (5-21 July) were spent measuring total $\mathrm{OH}$ reactivity below the forest canopy, while measurements above the canopy were conducted on 18 days ( 22 July- 8 August); this included four days of measurements at the $21 \mathrm{~m}$ level. Total $\mathrm{OH}$ reactivity was measured continuously with a time resolution of approximately $2.5 \mathrm{~min}$, corresponding to the time required for measurement of a single $\mathrm{OH}$ decay. Measurements of the $\mathrm{OH}$ loss rate in $\mathrm{N}_{2}\left(k_{b}\right.$ in Eq. 4$)$ were performed on 3 July, 10 July, 16 July, and 7 August.

\section{Results}

All relevant measurements, including total $\mathrm{OH}$ reactivity and ambient VOC mixing ratios, were averaged over a $10 \mathrm{~min}$ time step. Total $\mathrm{OH}$ reactivity was calculated from all measurements listed in Table 2. The temperature measured within the flow tube was used to calculate temperature-dependent rate constants. Furthermore, only 


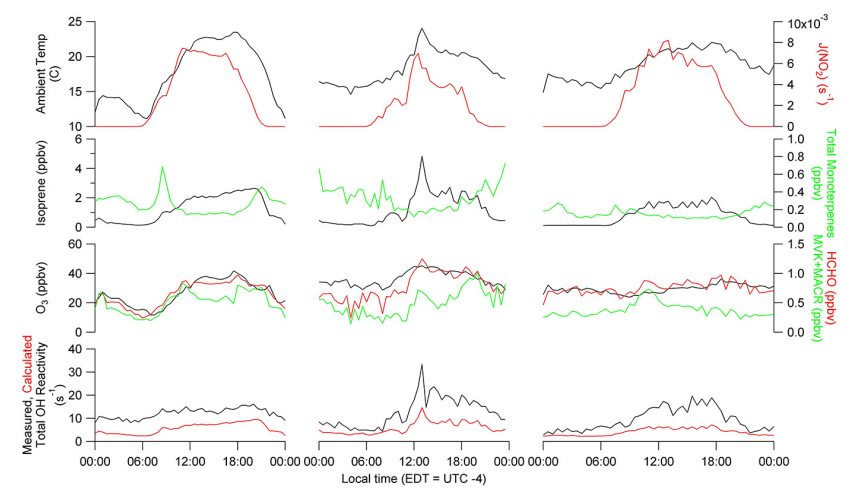

Fig. 4. Thirty min diurnal averages of measurements for the $6 \mathrm{~m}$ (left), $21 \mathrm{~m}$ (center), and $31 \mathrm{~m}$ (right) heights.

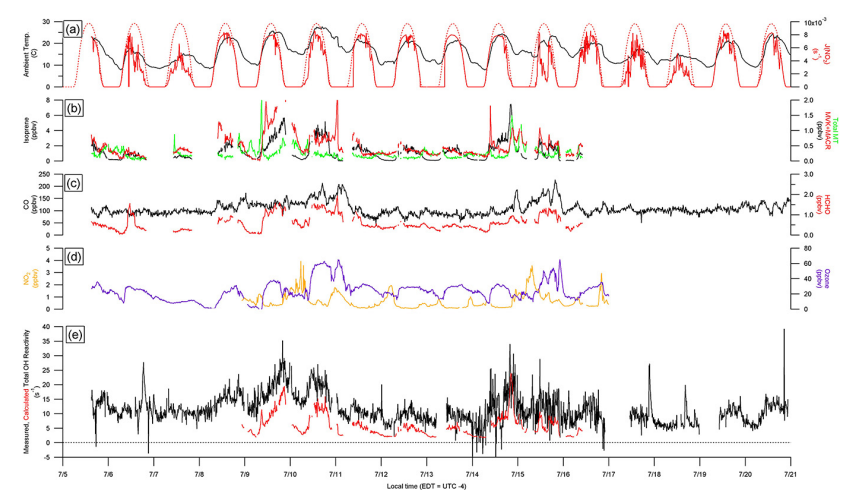

Fig. 5. Time series of $10 \mathrm{~min}$ averages for the $6 \mathrm{~m}$ height. The dashed line in panel a indicates values of $J\left(\mathrm{NO}_{2}\right)$ calculated by the TUV 4.4 model for clear-sky conditions.

total $\mathrm{OH}$ reactivity measurements that were coincident with $\mathrm{VOC}$ and $\mathrm{NO}_{\mathrm{x}}$ measurements are included in comparisons of measured and calculated $\mathrm{OH}$ reactivity. Measurements of ambient $\mathrm{NO}, \mathrm{SO}_{2}, \mathrm{HONO}$, and glyoxal mixing ratios have not been used in the $\mathrm{OH}$ reactivity analysis, as their total contribution to the $\mathrm{OH}$ reactivity is less than $0.15 \mathrm{~s}^{-1}$.

Figure 4 shows the $30 \mathrm{~min}$ diurnal average values of ambient temperature, $J\left(\mathrm{NO}_{2}\right)$ and $\mathrm{OH}$ reactivity, as well as ambient mixing ratios of ozone and some VOCs, at the 6,21, and $31 \mathrm{~m}$ heights. Individual time series of the measurements are shown as Figs. 5-7. Figure 8 shows the 30 min diurnal average values of $\mathrm{OH}$ reactivity and the speciated contributions of trace gases for the 6,21, and $31 \mathrm{~m}$ heights. Average ambient daytime temperatures from 12:00 to 18:00 span the same range of values among the three heights $\left(20-26^{\circ} \mathrm{C}\right.$, Fig. 4), although the average diurnal variation in temperature at $6 \mathrm{~m}$ $\left(12.4^{\circ} \mathrm{C}\right)$ is greater than that at $21 \mathrm{~m}\left(9.5^{\circ} \mathrm{C}\right)$ or $31 \mathrm{~m}\left(7.2^{\circ} \mathrm{C}\right)$ (Fig. 4, top panels). The magnitude of the measured $\mathrm{OH}$ reactivity was dependent on temperature, as the days with the highest ambient temperatures $\left(20-25^{\circ} \mathrm{C}\right)$ exhibited some of the highest measured $\mathrm{OH}$ reactivity $(10,24,27$ and 28 July) (Figs. 5-7, panel e).

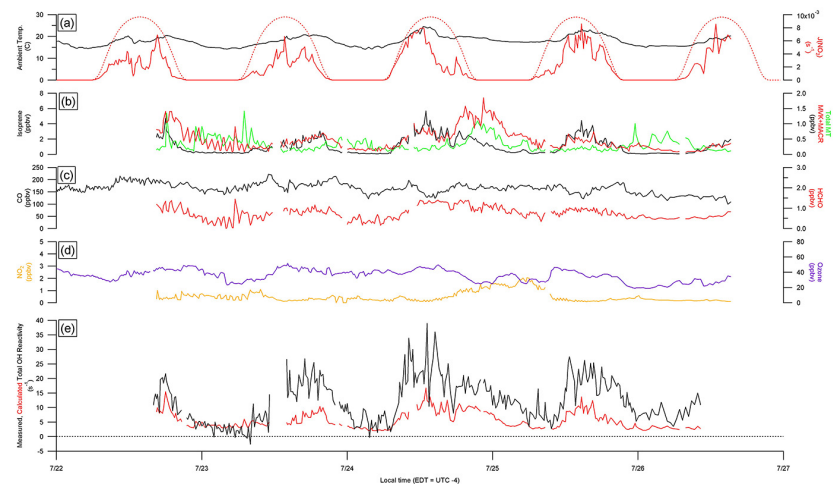

Fig. 6. Time series of $10 \mathrm{~min}$ averages for the $21 \mathrm{~m}$ height. The dashed line in panel a indicates values of $J\left(\mathrm{NO}_{2}\right)$ calculated by the TUV 4.4 model for clear-sky conditions.

The measured $\mathrm{OH}$ reactivity at all heights shows a distinct diurnal trend, with diurnal averages ranging $8-16 \mathrm{~s}^{-1}$ at $6 \mathrm{~m}, 5-33 \mathrm{~s}^{-1}$ at $21 \mathrm{~m}$, and $3-20 \mathrm{~s}^{-1}$ at $31 \mathrm{~m}$ (Fig. 4, bottom panels; Fig. 8). The diurnal trend in the measured $\mathrm{OH}$ reactivity is especially pronounced at the $21 \mathrm{~m}$ height. As expected in a site dominated by isoprene emissions (Westberg, 2001), isoprene was the dominant contributor to $\mathrm{OH}$ reactivity during the daytime hours, contributing $60-70 \%$ of the calculated $\mathrm{OH}$ reactivity on average at all heights from 12:00 to $18: 00$ (Fig. 8). However, the contribution of isoprene decreased to $20-40 \%$ when compared to the measured $\mathrm{OH}$ reactivity for the 21 and $31 \mathrm{~m}$ heights. Isoprene mixing ratios were similar at each height, with sustained daily maxima of around $2 \mathrm{ppbv}$, although there were several high-temperature events (7 July, 10 July, 24 July, 27 July) where the isoprene mixing ratios ranged from 4 to 6 ppbv (Figs. 5-7, panel b). Oxygenated VOCs (OVOCs, which include methyl vinyl ketone, methacrolein, methyl ethyl ketone, acetone, formaldehyde, acetaldehyde, methanol, and methyl peroxide) were the next largest contributor during the daytime, contributing 10$15 \%$ to the calculated $\mathrm{OH}$ reactivity from 12:00 to 18:00. Among these, MVK + MACR was the largest contributor, accounting for 30 to $50 \%$ of the $\mathrm{OH}$ reactivity from OVOCs during this time period. Mixing ratios of MVK + MACR were typically $0.25-1.0 \mathrm{ppbv}$ on average at each height, with some diurnal variation, most evident at $6 \mathrm{~m}$ (Fig. 4). Typical HCHO mixing ratios were between 0.5 and $1.0 \mathrm{ppbv}$ for all heights (Fig. 4), although the $\mathrm{HCHO}$ mixing ratio was close to 2.0 ppbv during the 27-28 July episode (Fig. 7, panel c).

Monoterpenes, oxygenated VOCs and CO were the dominant contributors to $\mathrm{OH}$ reactivity at night, each contributing roughly $20-30 \%$ of the calculated $\mathrm{OH}$ reactivity on average from 00:00 to 06:00 and from 20:00 to 00:00 for all heights. Mixing ratios of monoterpenes were highest at night, approaching 1 ppbv at $6 \mathrm{~m}$ and $21 \mathrm{~m}$, but less than $0.5 \mathrm{ppbv}$ at $31 \mathrm{~m}$ (Figs. 5-7, panel b). Mixing ratios of CO showed very 


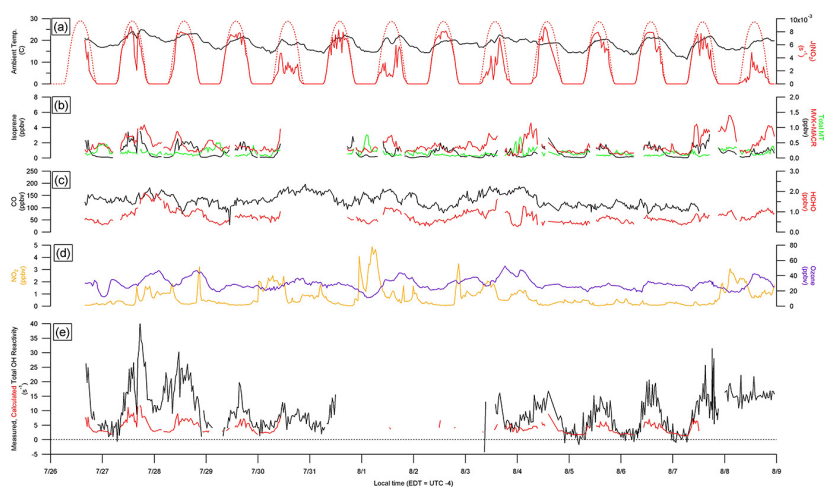

Fig. 7. Time series of $10 \mathrm{~min}$ averages for the $31 \mathrm{~m}$ height. The dashed line in panel a indicates values of $J\left(\mathrm{NO}_{2}\right)$ calculated by the TUV 4.4 model for clear-sky conditions.

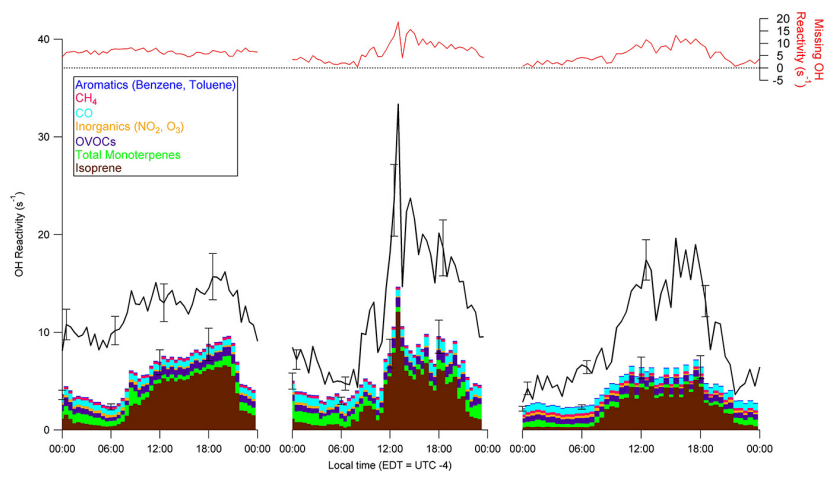

Fig. 8. Thirty min diurnal averages for $\mathrm{OH}$ reactivity at the $6 \mathrm{~m}$ (left), $21 \mathrm{~m}$ (center), and $31 \mathrm{~m}$ (right) heights. Measured $\mathrm{OH}$ reactivity is shown by the line; calculated $\mathrm{OH}$ reactivity is indicated by the colored bars. OVOCs include methyl vinyl ketone, methacrolein, MEK, acetone, formaldehyde, acetaldehyde, methanol, and methyl peroxide. Top plots show the missing reactivity at each height. Error bars on the calculated reactivity represent the uncertainty propagated from the $1 \sigma$ uncertainties on the rate constants and concentrations of each species; error bars on the measured $\mathrm{OH}$ reactivity represent the $1 \sigma$ uncertainty on a single $\mathrm{OH}$ reactivity measurement, propagated from uncertainties on measurements of flow velocity, injector distance, $k_{b}$, and the correction factor described in Sect. 2.1.

little diurnal variation, with an average mixing ratio on the order of $150 \mathrm{ppbv}$ that approached $200 \mathrm{ppbv}$ on some days.

The $\mathrm{OH}$ reactivity measured below the canopy at the $6 \mathrm{~m}$ height was generally lower than that measured above the canopy during the day (10:00-18:00), with an average missing OH reactivity of $6.2 \pm 0.2 \mathrm{~s}^{-1}$ (46\% of total; Figs. 4, 8). Missing reactivity was also observed at night (00:00$06: 00,22: 00-00: 00)$ at this height, with an average value of $6.5 \pm 0.2 \mathrm{~s}^{-1}$ ( $65 \%$ of total). Above the canopy the average missing reactivity during the day (10:00-18:00) was on average $10.3 \pm 1 \mathrm{~s}^{-1}$ ( $48 \%$ of total) for $21 \mathrm{~m}$ and $9.32 \pm 0.5 \mathrm{~s}^{-1}$ (61\% of total) for $31 \mathrm{~m}$ (Figs. 5-7, panel e). At night, the discrepancy between the measured and calculated reactivity is smaller than during the day (Figs. 4, 8). These results suggest that there are additional sinks of $\mathrm{OH}$ that were not captured by the trace gas measurements.

The $\mathrm{OH}$ reactivity measurements and calculations were also binned by the ambient temperatures observed at each height (Fig. 9) to investigate the temperature dependence of $\mathrm{OH}$ reactivity contributions (Di Carlo et al., 2004; Mao et al., 2012). The width of each bin is $1 \mathrm{~K}$, with the bin centered on the temperature of interest. At all heights, isoprene is the dominant contributor to the calculated $\mathrm{OH}$ reactivity at temperatures higher than $293 \mathrm{~K}$, while monoterpenes and CO dominate the $\mathrm{OH}$ reactivity at temperatures lower than $291 \mathrm{~K}$. The negative value at $284 \mathrm{~K}$ observed at $31 \mathrm{~m}$ likely reflects the overestimation of the background reactivity at this height as discussed above. The measurements at $31 \mathrm{~m}$ likely reflect a lower limit to the total $\mathrm{OH}$ reactivity (lower by $1-2 \mathrm{~s}^{-1}$ ). An inspection of Fig. 9 (top and center panels) indicates that the missing $\mathrm{OH}$ reactivity at 21 and $31 \mathrm{~m}$ exhibit a dependence on ambient temperature, with the missing reactivity increasing with increasing temperature. This trend is similar to that observed previously at this site during the PROPHET 2000 campaign (Di Carlo et al., 2004), although the magnitude of the missing $\mathrm{OH}$ reactivity is higher in this study. Di Carlo et al. (2004) observed $1-4 \mathrm{~s}^{-1}$ of missing reactivity over the temperature range of $286-298 \mathrm{~K}$, whereas values up to 14 and $24 \mathrm{~s}^{-1}$ were observed for this study over the same temperature range for the 21 and $31 \mathrm{~m}$ heights, respectively. In contrast, the measurements below canopy at the $6 \mathrm{~m}$ height do not reveal a significant trend of missing reactivity with increasing temperature (Fig. 9, bottom panel).

\section{Discussion}

As mentioned above, Di Carlo et al. (2004) found that their measurements of total $\mathrm{OH}$ reactivity made during summer 2000 above the canopy at the PROPHET site were $1-4 \mathrm{~s}^{-1}$ greater than the $\mathrm{OH}$ reactivity calculated from measurements of the mixing ratios of $\mathrm{OH}$ sinks. From these observations, these authors suggested that emissions of an unmeasured highly reactive terpene could be responsible for the missing $\mathrm{OH}$ reactivity. However, subsequent measurements of total monoterpenes and sesquiterpenes at this site suggest that these compounds would only account for $0.7 \mathrm{~s}^{-1}$ of the reported missing $\mathrm{OH}$ reactivity, which corresponds to $30 \%$ of the missing $\mathrm{OH}$ reactivity observed at $296 \mathrm{~K}$ during PROPHET 2000 (Kim et al., 2009).

Di Carlo et al. (2004) based their conclusions on the temperature dependence of the observed missing $\mathrm{OH}$ reactivity. The missing $\mathrm{OH}$ reactivity derived from these measurements was fitted with an equation often used to describe temperature-dependent emissions of monoterpenes (Guenther et al., 1993; Schade et al., 1999):

$E(T)=E(293) \exp (\beta(T-293))$. 


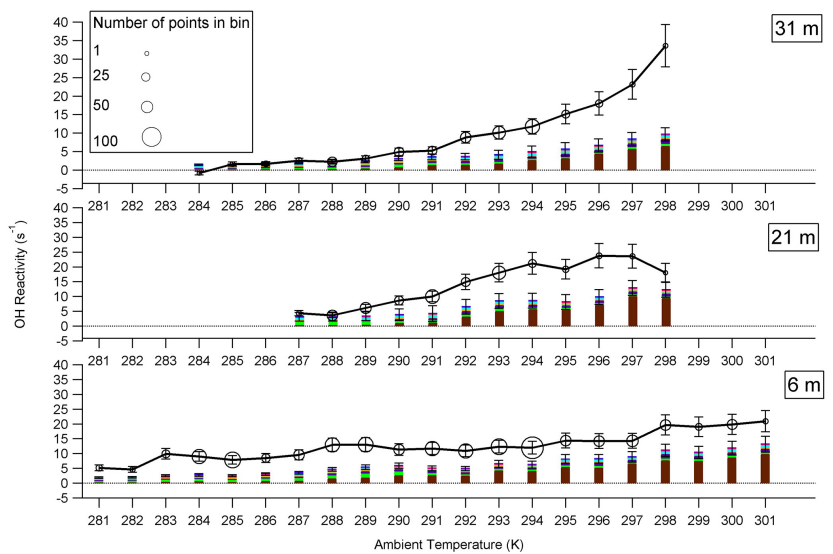

Fig. 9. Measured (lines, markers) and calculated (bars) total $\mathrm{OH}$ reactivity, binned by ambient temperature for the $6 \mathrm{~m}$ (bottom), $21 \mathrm{~m}$ (center), and $31 \mathrm{~m}$ (top) heights. The color scheme for the bars is the same as that for Fig. 8. Error bars on the calculated reactivity represent the uncertainty propagated from the $1 \sigma$ uncertainties on the rate constants and concentrations of each species; error bars on the measured $\mathrm{OH}$ reactivity represent the $1 \sigma$ uncertainty on a single $\mathrm{OH}$ reactivity measurement, propagated from uncertainties on measurements of flow velocity, injector distance, $k_{b}$, and the correction factor described in Sect. 2.1.

$E(T)$ represents the emission rate for a given temperature $T$. To compare the temperature dependence of the missing $\mathrm{OH}$ reactivity to the temperature dependence of monoterpene emissions described by Eq. (5), the temperature-dependent missing $\mathrm{OH}$ reactivity $\mathrm{MR}(T)$ was substituted for $E(T)$ and MR(293) for $E$ (293) in Eq. (5). Typical values for $\beta$, which is the factor representing the temperature dependence of the emission, range from 0.057 to $0.144 \mathrm{~K}^{-1}$ for a variety of monoterpenes, including $\alpha$ - and $\beta$-pinene, as well as limonene (Guenther et al., 1993). These values have been estimated from measurements of emission rates. The large variability in $\beta$ is to be expected, as emission of monoterpenes can vary with plant species, location, and even among leaves on a specific plant. Experimental error can also factor into the variability in $\beta$ (Guenther et al., 1993).

The missing $\mathrm{OH}$ reactivity measurements from the 2000 PROPHET campaign were fit to Eq. (5), resulting in a value for $\beta$ of 0.11 (Di Carlo et al., 2004), a value similar to that previously observed for the temperature-dependent emission of $\Delta$-3-carene (Schade et al., 1999). A similar treatment of the missing $\mathrm{OH}$ reactivity seen at the BEARPEX 2009 campaign, in which the missing $\mathrm{OH}$ reactivity is attributed to BVOC oxidation products, resulted in a $\beta$ value of 0.17 (Mao et al., 2012), slightly higher than the upper limit of $0.144 \mathrm{~K}^{-1}$ observed for monoterpene emissions.

The missing $\mathrm{OH}$ reactivity data from CABINEX for the 21 and $31 \mathrm{~m}$ heights was also fit to Eq. (5). In contrast to the results described above, the values of $\beta$ determined from the fits of the data for the 21 and $31 \mathrm{~m}$ heights $(0.34$ and 0.35 , respectively) are not consistent with those observed

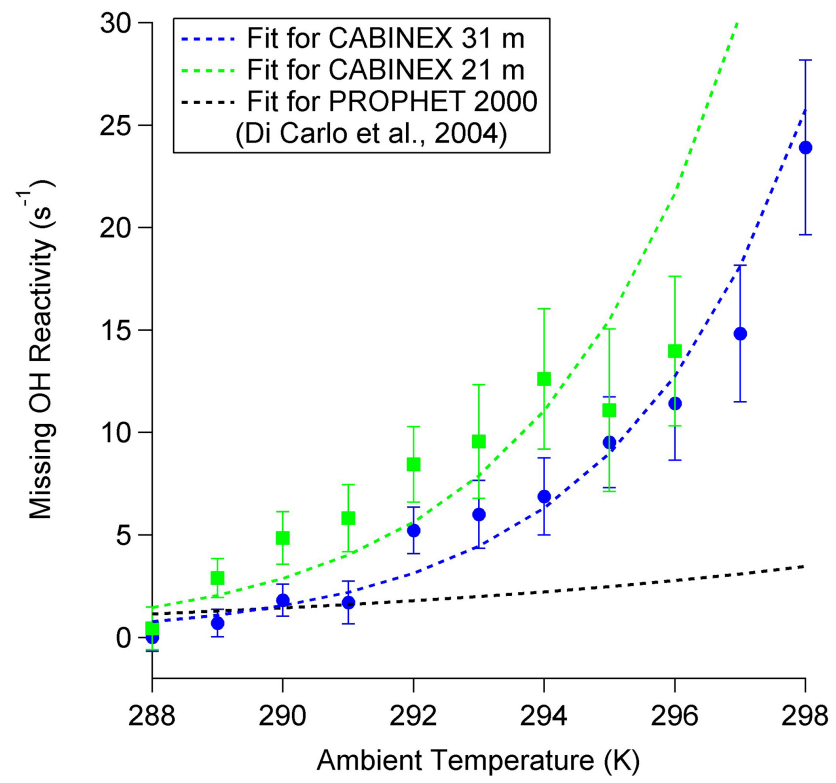

Fig. 10. Missing $\mathrm{OH}$ reactivity, binned by ambient temperature for the $21 \mathrm{~m}$ (squares) and $31 \mathrm{~m}$ (circles) heights for temperatures from 288 to 298 K. Dashed lines indicate fits to Eq. (5) for the $21 \mathrm{~m}$ height (green), $31 \mathrm{~m}$ height (blue), and the fit of the measurements from PROPHET 2000 reported by Di Carlo et al. (2004) (black). For the fits of the CABINEX data, MR(293) in Eq. (5) was determined from exponential fits of the measurements from 21 and $31 \mathrm{~m}$. Due to the low number of points in the 297 and $298 \mathrm{~K}$ bins for the $21 \mathrm{~m}$ height, these points have not been included in the fit nor on this figure. Error bars represent the uncertainty $(1 \sigma)$ propagated from the uncertainties on individual measurements of $\mathrm{OH}$ reactivity (described in caption to Fig. 9) and the calculated $\mathrm{OH}$ reactivity.

during PROPHET 2000 and attributed to monoterpene emissions (Fig. 10). However, comparisons of $\beta$ factors derived for monoterpene emissions must be made with caution, as $\beta$ may not be the best metric for determination of the source of missing $\mathrm{OH}$ reactivity. Missing $\mathrm{OH}$ reactivity can be influenced by processes that do not affect BVOC emissions, such as boundary layer height and vertical mixing.

In addition, missing $\mathrm{OH}$ reactivity at the $31 \mathrm{~m}$ height does not appear to correlate with the measured mixing ratio of total monoterpenes (Fig. 11). These results are consistent with branch enclosure measurements of total $\mathrm{OH}$ reactivity during CABINEX that found that the measured $\mathrm{OH}$ reactivity was consistent with the calculated reactivity based on the measured VOC concentrations, including measurements of isoprene and monoterpene concentrations (Kim et al., 2011). These two findings indicate that directly emitted BVOCs are likely not the cause of the missing $\mathrm{OH}$ reactivity observed at this site.

The high missing $\mathrm{OH}$ reactivity measured during $\mathrm{CAB}$ INEX at temperatures greater than $296 \mathrm{~K}$ is larger than the missing $\mathrm{OH}$ reactivity observed at these temperatures by $\mathrm{Di}$ Carlo et al. (2004) during the 2000 PROPHET campaign. 


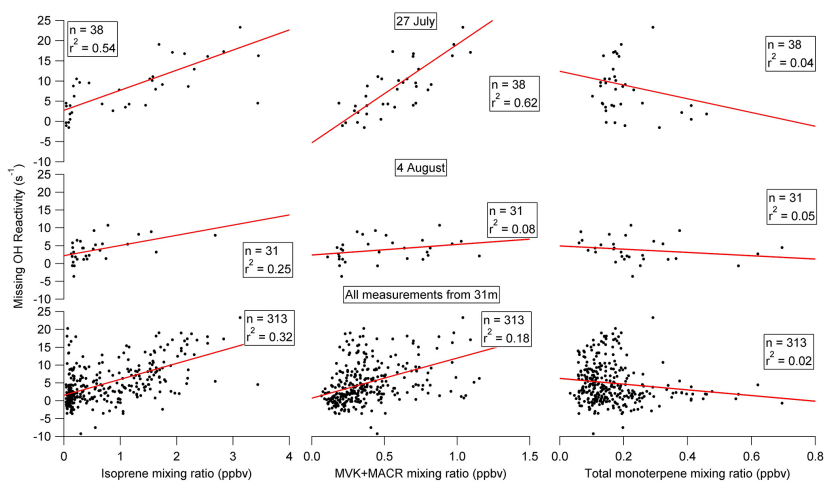

Fig. 11. Plots of missing $\mathrm{OH}$ reactivity from the $31 \mathrm{~m}$ height as a function of ambient isoprene, MVK + MACR, and total monoterpene mixing ratios for 27 July (top panels), 4 August (middle panels), and the entire $31 \mathrm{~m}$ data set (bottom panels).

However, the high missing $\mathrm{OH}$ reactivity observed during CABINEX at $31 \mathrm{~m}$ occurred during a two-day high temperature event (27-28 July, Fig. 7). The reason for the high measured missing $\mathrm{OH}$ reactivity during the $27-28$ July episode is unclear, but may be related to either a transport event or a period of high photochemical activity, as the measured mixing ratio of $\mathrm{HCHO}$ was elevated during this event, with a peak mixing ratio of approximately 2 ppbv (Fig. 7, panel c, red trace) compared to an average value of 1 ppbv observed during the remaining $31 \mathrm{~m}$ measurement period (Fig. 4). Mixing ratios of isoprene during this episode were also $1-2 \mathrm{ppbv}$ greater than the average values observed during the remaining measurement period at this height, as well as approximately $1 \mathrm{ppbv}$ greater than the average daytime measurements during PROPHET 1998 (Apel et al., 2002), where conditions were similar to those during PROPHET 2000 (Di Carlo et al., 2004). The higher mixing ratios of isoprene could lead to higher concentrations of oxidation products, as the higher mixing ratios of MVK + MACR and formaldehyde suggest higher photochemical activity during this episode. Both of these possibilities will be explored further in a forthcoming paper (Hansen et al., 2014). It must be noted that many compounds are absent from the suite of measurements listed in Table 2, including $\mathrm{C} 2-\mathrm{C} 4$ alkenes and $\mathrm{C} 2$ C12 alkanes, some of which may be emitted by plants and soil (Kesselmeier and Staudt, 1999). These compounds were previously measured at this site during the PROPHET98 campaign with mixing ratios between 50 and 300 pptv. Depending on whether the median or maximum mixing ratios were used for the calculation, $\mathrm{C} 2-\mathrm{C} 4$ alkenes and $\mathrm{C} 2-\mathrm{C} 12$ alkanes could contribute 0.2 to $1.5 \mathrm{~s}^{-1}$ to the ambient $\mathrm{OH}$ reactivity. When other compounds from the 1998 data set (such as C5-C6 alkenes, substituted aromatics, and haloalkanes) were included, the range of $\mathrm{OH}$ reactivity contributed by these unmeasured compounds increases to 1.1 to $3.8 \mathrm{~s}^{-1}$. This could account for 5 to $16 \%$ of the missing $\mathrm{OH}$ reac- tivity at $298 \mathrm{~K}$ and $31 \mathrm{~m}$ and 10 to $33 \%$ of the missing $\mathrm{OH}$ reactivity at $296 \mathrm{~K}$ and $31 \mathrm{~m}$.

Recent studies have suggested that unmeasured BVOC oxidation products from isoprene could explain some of the missing $\mathrm{OH}$ reactivity seen within isoprene-dominated environments (Karl et al., 2009; Kim et al., 2011). A timedependent box model by Kim et al. (2011) for the PROPHET site found that first-generation unmeasured isoprene oxidation products could contribute approximately $7 \%$ of the $\mathrm{OH}$ reactivity relative to the contribution of isoprene. These values correspond to approximately $8 \%$ of the missing $\mathrm{OH}$ reactivity (at $298 \mathrm{~K}$ ) observed by Di Carlo et al. (2004) and $2 \%$ of the missing $\mathrm{OH}$ reactivity from the $31 \mathrm{~m}$ height (at $298 \mathrm{~K}$ ) observed during CABINEX.

However, Karl et al. (2009) examined the chemistry of isoprene oxidation products in Amazonia using several models of isoprene chemistry. They found that isoprene oxidation products could account for a significant fraction of the total $\mathrm{OH}$ reactivity when the contribution of higher-generation oxidation products towards total $\mathrm{OH}$ reactivity was included. Depending on the exposure to $\mathrm{OH}$, these models predicted that the overall $\mathrm{OH}$ reactivity from isoprene oxidation products could be as much as $150 \%$ of the $\mathrm{OH}$ reactivity from isoprene. The results from this study suggest that unmeasured products from isoprene oxidation could explain a significant fraction of the missing $\mathrm{OH}$ reactivity seen above the canopy during CABINEX.

Figure 11 shows linear fits of the measured missing reactivity at the $31 \mathrm{~m}$ height as a function of the measured mixing ratios of isoprene, MVK + MACR, and total monoterpenes. Although the correlation coefficients are low, the results suggest that the missing reactivity is more likely related to isoprene and its oxidation products rather than monoterpene emissions. Although not shown, the linear regression of missing $\mathrm{OH}$ reactivity as a function of methyl peroxide mixing ratio is similar to that for the linear regression of missing $\mathrm{OH}$ reactivity as a function of MVK + MACR mixing ratio. The correlation coefficient for the fit of the observed missing $\mathrm{OH}$ reactivity as a function of MVK + MACR mixing ratio is higher on 27 July $\left(R^{2}=0.62\right)$, when the missing $\mathrm{OH}$ reactivity is high (Fig. 11, top), than on a day when the missing $\mathrm{OH}$ reactivity is low such as on 4 August (Fig. 11, center) $\left(R^{2}=0.08\right)$. These results suggest that the missing $\mathrm{OH}$ reactivity observed on 27-28 July may have been enhanced by unmeasured BVOC oxidation products due to more efficient photochemistry during this period. Future work will involve estimating the contribution of unmeasured oxidation products from isoprene, monoterpenes, and sesquiterpenes to the total $\mathrm{OH}$ reactivity through model simulations incorporating the explicit chemistry included in the Master Chemical Mechanism, version 3.2 (Hansen et al., 2014).

Although missing $\mathrm{OH}$ reactivity was observed above the forest canopy during CABINEX for temperatures greater than $293 \mathrm{~K}$, the $\mathrm{OH}$ reactivity observed below the canopy over the same temperature range is in better agreement with 
the calculated reactivity (Fig. 9). However, the mixing ratios of measured VOCs and inorganic trace species were found to be similar among the three heights, including the mixing ratios of isoprene oxidation products such as MVK + MACR (Figs. 5-7). Thus, given the similar composition above and below the canopy, one would expect to observe missing $\mathrm{OH}$ reactivity at $6 \mathrm{~m}$ that was comparable in magnitude to that observed at 21 and $31 \mathrm{~m}$. It should be noted that there was one episode of significant high missing $\mathrm{OH}$ reactivity at the $6 \mathrm{~m}$ height that occurred on 10 July (Fig. 5, panel e). As in the episode on 27-28 July at $31 \mathrm{~m}$, the mixing ratios of isoprene and MVK+MACR were elevated on this day, with daytime mixing ratios of isoprene approximately $4 \mathrm{ppbv}$ (Fig. 5, panel b), and daytime MVK + MACR mixing ratios approximately 0.75 ppbv (Fig. 5, panel b). In addition, $\mathrm{NO}_{2}$ mixing ratios were elevated (1-2 ppbv, Fig. 5, panel d) in the early morning. This again suggests that the elevated $\mathrm{OH}$ reactivity was the result of either a transport event or a period of elevated photochemical activity.

It is possible that some of the BVOC oxidation products suspected of being the source of the missing $\mathrm{OH}$ reactivity above the canopy were lost to deposition within the forest canopy during turbulent mixing. A study incorporating ecosystem-scale flux measurements from six field campaigns has shown that dry deposition onto vegetation represents a significant loss of oxygenated VOCs in forested environments (Karl et al., 2010). Furthermore, an examination of vertical deposition profiles indicates that almost all $(>97 \%)$ of the deposition of oxygenated VOCs occurs in the upper $70 \%$ of the forest canopy. For most of the species investigated (hydroxyacetone, C4-carbonyls, glycolaldehyde, nopinone, MVK+MACR), the dry deposition velocities were greater than $1 \mathrm{~cm} \mathrm{~s}^{-1}$ within this regime. Modeling studies incorporating 1-D models such as the one used in Bryan et al. (2012) and Mogensen et al. (2011) would also be useful to test whether deposition processes are efficient enough to remove oxygenated species from air masses injected within and below the canopy.

In contrast to the measurements made above the canopy, significant missing reactivity was observed below canopy at night when temperatures were below approximately $293 \mathrm{~K}$ (Figs. 4, 5, 8, 9). Missing OH reactivity was also observed at low temperatures at the top of the forest canopy during the BEARPEX 2007 field campaign (Wolfe et al., 2011); this was attributed to a missing source of formaldehyde. A modeling study of a boreal forest performed by Mogensen et al. (2011) suggests that summertime $\mathrm{OH}$ reactivity is higher below the canopy during the night but decreases during the day due to efficient mixing, in contrast to measurements at this site (Sinha et al., 2010). The missing OH reactivity seen below the canopy during CABINEX may be due to enhanced oxidation of mono- and sesquiterpene emissions in the stable nighttime boundary layer producing unmeasured oxidation products that accumulate below the forest canopy due to suppressed turbulent mixing, or oxidation products pro- duced during the day that are trapped below the canopy at night. However, in contrast to the above-canopy observations, the missing reactivity observed below the canopy does not exhibit any consistent trend with the mixing ratios of isoprene, MVK + MACR, or monoterpenes (Fig. S3), even though some of the periods of greatest missing reactivity occurred during periods when the mixing ratio of ozone below the canopy was high (9 and 10 July, Fig. 5). Additional measurements of $\mathrm{OH}$ reactivity and biogenic VOCs below the forest canopy are needed to determine the source of this missing reactivity. Because these measurements of $\mathrm{OH}$ reactivity were performed during three different time periods of varying duration, measurements of $\mathrm{OH}$ reactivity with rapid switching between heights will be necessary to confirm these results.

\section{Conclusions}

Measured total $\mathrm{OH}$ reactivity above the forest canopy during the CABINEX campaign was significantly greater than that calculated based on measurements of the concentration of $\mathrm{OH}$ sinks, similar to that observed previously at this site. However, in contrast to these previous results, the measured missing $\mathrm{OH}$ reactivity in this study is not consistent with the emission of unmeasured BVOCs. Instead, the missing $\mathrm{OH}$ reactivity observed above the canopy may be due to unmeasured oxidation products, consistent with other studies (Karl et al., 2009; Kim et al., 2011; Edwards et al., 2013). A comprehensive modeling study focusing on VOC oxidation above the forest canopy is necessary to determine whether secondary species formed during the oxidation of isoprene are present at concentrations that are high enough to explain the missing $\mathrm{OH}$ reactivity observed in this study, or whether additional reactive gases are necessary to explain these observations. This work will be the focus of an upcoming publication (Hansen et al., 2014).

In contrast, the missing $\mathrm{OH}$ reactivity observed below the forest canopy for temperatures greater than approximately $293 \mathrm{~K}$ was in better agreement with the calculated reactivity based on measurements of isoprene, monoterpenes, and a few BVOC oxidation products such as methacrolein, methyl vinyl ketone, and formaldehyde. Although the concentrations of some oxidation products below canopy such as MVK + MACR are similar to those observed above canopy due to efficient in-canopy mixing (Bryan et al., 2012), species responsible for the missing $\mathrm{OH}$ reactivity above the canopy may be lost to deposition within the forest canopy and may not contribute to the $\mathrm{OH}$ reactivity at the $6 \mathrm{~m}$ height. Less efficient mixing below the canopy may also trap oxidation products produced at the $6 \mathrm{~m}$ height. However, as the measurements at the three heights were performed at different time periods, the influence of other factors between these heights cannot be ruled out. Additional 1-D modeling of deposition processes within and below the canopy as 
well as additional sequential measurements of $\mathrm{OH}$ reactivity and associated OVOCs both above and below forest canopies would be useful to confirm the results presented in this study.

\section{Supplementary material related to this article is available online at http://www.atmos-chem-phys.net/14/ 2923/2014/acp-14-2923-2014-supplement.pdf.}

Acknowledgements. This work was funded by National Science Foundation grants AGS-0612738 and AGS-0904167. R. F. Hansen and S. M. Griffith also received support from the BiosphereAtmosphere Research and Training (BART) program. We thank P. Shepson for helpful comments. We also thank the staff of the University of Michigan Biological Station for their support.

Edited by: J. Liggio

\section{References}

Apel, E. C., Riemer, D. D., Hills, A., Baugh, W., Orlando, J., Faloona, I., Tan, D., Brune, W., Lamb, B., Westberg, H., Carroll, M. A., Thornberry, T., and Geron, C. D.: Measurement and interpretation of isoprene fluxes and isoprene, methacrolein, and methyl vinyl ketone mixing ratios at the PROPHET site during the 1998 intensive, J. Geophys. Res., 107, 4034, doi:10.1029/2000JD000225, 2002.

Atkinson, R.: Gas-Phase Tropospheric Chemistry of Volatile Organic Compounds: 1. Alkanes and Alkenes, J. Phys. Chem. Ref. Data, 26, 215-290, 1997.

Atkinson, R.: Kinetics of the gas-phase reactions of $\mathrm{OH}$ radicals with alkanes and cycloalkanes, Atmos. Chem. Phys., 3, 22332307, doi:10.5194/acp-3-2233-2003, 2003.

Atkinson, R., Arey, J., Aschmann, S. M., Corchnoy, S. B., and Shu, Y.: Rate Constants for the Gas-Phase Reactions of cis-3-Hexen1-ol, cis-3-Hexenylacetate, trans-2-Hexenal, and Linalool with $\mathrm{OH}$ and $\mathrm{NO}_{3}$ Radicals and $\mathrm{O}_{3}$ at $296 \pm 2 \mathrm{~K}$, and $\mathrm{OH}$ Radical Formation Yields from the $\mathrm{O}_{3}$ Reactions, Int. J. Chem. Kinet., 27, 941-955, 1995.

Atkinson, R., Baulch, D. L., Cox, R. A., Crowley, J. N., Hampson, R. F., Hynes, R. G., Jenkin, M. E., Rossi, M. J., Troe, J., and IUPAC Subcommittee: Evaluated kinetic and photochemical data for atmospheric chemistry: Volume II - gas phase reactions of organic species, Atmos. Chem. Phys., 6, 3625-4055, doi:10.5194/acp-6-3625-2006, 2006.

Bryan, A. M., Bertman, S. B., Carroll, M. A., Dusanter, S., Edwards, G. D., Forkel, R., Griffith, S., Guenther, A. B., Hansen, R. F., Helmig, D., Jobson, B. T., Keutsch, F. N., Lefer, B. L., Pressley, S. N., Shepson, P. B., Stevens, P. S., and Steiner, A. L.: Incanopy gas-phase chemistry during CABINEX 2009: sensitivity of a 1-D canopy model to vertical mixing and isoprene chemistry, Atmos. Chem. Phys., 12, 8829-8849, doi:10.5194/acp-12-88292012, 2012.

Carroll, M. A., Bertman, S. B., and Shepson, P. B.: Overview of the Program on Research for Oxidants: PHotochemistry, Emissions, and Transport (PROPHET) 1998 summer intensive, J. Geophys. Res., 106, 24275-24288, 2001.

Chatani, S., Shimo, N., Matsunaga, S., Kajii, Y., Kato, S., Nakashima, Y., Miyazaki, K., Ishii, K., and Ueno, H.: Sensitivity analyses of $\mathrm{OH}$ missing sinks over Tokyo metropolitan area in the summer of 2007, Atmos. Chem. Phys., 9, 8975-8986, doi:10.5194/acp-9-8975-2009, 2009.

Di Carlo, P., Brune, W. H., Martinez, M., Harder, H., Lesher, R., Ren, X., Thornberry, T., Carroll, M. A., Young, V., Shepson, P. B., Reimer, D., Apel, E., and Campbell, C.: Missing OH Reactivity in a Forest: Evidence for Unknown Reactive Biogenic VOCs, Science, 304, 722-725, 2004.

Dolgorouky, C., Gros, V., Sarda-Esteve, R., Sinha, V., Williams, J., Marchand, N., Sauvage, S., Poulain, L., Sciare, J., and Bonsang, B.: Total OH reactivity measurements in Paris during the 2010 MEGAPOLI winter campaign, Atmos. Chem. Phys., 12, 95939612, doi:10.5194/acp-12-9593-2012, 2012.

Dusanter, S., Vimal, D., and Stevens, P. S.: Technical note: Measuring tropospheric $\mathrm{OH}$ and $\mathrm{HO}_{2}$ by laser-induced fluorescence at low pressure. A comparison of calibration techniques, Atmos. Chem. Phys., 8, 321-340, doi:10.5194/acp-8-321-2008, 2008.

Dusanter, S., Vimal, D., Stevens, P. S., Volkamer, R., and Molina, L. T.: Measurements of $\mathrm{OH}$ and $\mathrm{HO}_{2}$ concentrations during the MCMA-2006 field campaign - Part 1: Deployment of the Indiana University laser-induced fluorescence instrument, Atmos. Chem. Phys., 9, 1665-1685, doi:10.5194/acp-9-1665-2009, 2009.

Edwards, P. M., Evans, M. J., Furneaux, K. L., Hopkins, J., Ingham, T., Jones, C., Lee, J. D., Lewis, A. C., Moller, S. J., Stone, D., Whalley, L. K., and Heard, D. E.: OH reactivity in a South East Asian tropical rainforest during the Oxidant and Particle Photochemical Processes (OP3) project, Atmos. Chem. Phys., 13, 9497-9514, doi:10.5194/acp-13-9497-2013, 2013.

Ehhalt, D. H.: Atmospheric chemistry - Radical ideas, Science, 279, 1002-1003, 1998.

Goldstein, A. H. and Galbally, I. E.: Known and unexplored organic constituents in the earth's atmosphere, Environ. Sci. Technol., 41, 1514-1521, 2007.

Griffith, S. M., Hansen, R. F., Dusanter, S., Stevens, P. S., Alaghmand, M., Bertman, S. B., Carroll, M. A., Erickson, M., Galloway, M., Grossberg, N., Hottle, J., Hou, J., Jobson, B. T., Kammrath, A., Keutsch, F. N., Lefer, B. L., Mielke, L. H., O'Brien, A., Shepson, P. B., Thurlow, M., Wallace, W., Zhang, N., and Zhou, X. L.: $\mathrm{OH}$ and $\mathrm{HO}_{2}$ radical chemistry during PROPHET 2008 and CABINEX 2009 -Part 1: Measurements and model comparison, Atmos. Chem. Phys., 13, 5403-5423, doi:10.5194/acp-13-5403-2013, 2013.

Guenther, A. B., Zimmerman, P. R., Harley, P. C., Monson, R. K., and Fall, R.: Isoprene and Monoterpene Emission Rate Variability - Model Evaluations and Sensitivity Analyses, J. Geophys. Res.-Atmos., 98, 12609-12617, 1993.

Hansen, R. F., Griffith, S. M., Dusanter, S., Stevens, P. S., Bertman, S. B., Bryan, A. M., Carroll, M. A., Erickson, M. H., Flynn, J. H., Galloway, M. M., Grossberg, N., Hou, J., Jobson, B. T., Keutsch, F. N., Lefer, B. L., O’Brien, A., Shepson, P. B., Steiner, A. L., Thurlow, M., Wallace, H. W., Zhang, N., and Zhou, X. L.: Measurements of Total Hydroxyl Radical Reactivity during the CABINEX 2009 Field Campaign: Part 2 - Modeling of Hydroxyl Radical Reactivity, Atmos. Chem. Phys., in preparation, 2014. 
Holzinger, R., Lee, A., Paw, K. T., and Goldstein, U. A. H.: Observations of oxidation products above a forest imply biogenic emissions of very reactive compounds, Atmos. Chem. Phys., 5, 67-75, doi:10.5194/acp-5-67-2005, 2005.

Ingham, T., Goddard, A., Whalley, L. K., Furneaux, K. L., Edwards, P. M., Seal, C. P., Self, D. E., Johnson, G. P., Read, K. A., Lee, J. D., and Heard, D. E.: A flow-tube based laser-induced fluorescence instrument to measure $\mathrm{OH}$ reactivity in the troposphere, Atmos. Meas. Tech., 2, 465-477, doi:10.5194/amt-2-465-2009, 2009.

Jobson, B. T. and McCoskey, J. K.: Sample drying to improve $\mathrm{HCHO}$ measurements by PTR-MS instruments: laboratory and field measurements, Atmos. Chem. Phys., 10, 1821-1835, doi:10.5194/acp-10-1821-2010, 2010.

Karl, T., Guenther, A., Turnipseed, A., Tyndall, G., Artaxo, P., and Martin, S.: Rapid formation of isoprene photo-oxidation products observed in Amazonia, Atmos. Chem. Phys., 9, 7753-7767, doi:10.5194/acp-9-7753-2009, 2009.

Karl, T., Harley, P., Emmons, L., Thornton, B., Guenther, A., Basu, C., Turnipseed, A., and Jardine, K.: Efficient Atmospheric Cleansing of Oxidized Organic Trace Gases by Vegetation, Science, 330, 816-819, 2010.

Kesselmeier, J. and Staudt, M.: Biogenic Volatile Organic Compounds (VOC): An Overview on Emission, Physiology, and Ecology, J. Atmos. Chem., 33, 23-88, 1999.

Kim, S., Karl, T., Helmig, D., Daly, R., Rasmussen, R., and Guenther, A.: Measurement of atmospheric sesquiterpenes by proton transfer reaction-mass spectrometry (PTR-MS), Atmos. Meas. Tech., 2, 99-112, doi:10.5194/amt-2-99-2009, 2009.

Kim, S., Guenther, A., Karl, T., and Greenberg, J.: Contributions of primary and secondary biogenic VOC tototal $\mathrm{OH}$ reactivity during the CABINEX (Community Atmosphere-Biosphere INteractions Experiments)-09 field campaign, Atmos. Chem. Phys., 11, 8613-8623, doi:10.5194/acp-11-8613-2011, 2011.

Kovacs, T. A. and Brune, W. H.: Total OH Loss Rate Measurement, J. Atmos. Chem., 39, 105-122, 2001.

Kovacs, T. A., Brune, W. H., Harder, H., Martinez, M., Simpas, J. B., Frost, G. J., Williams, E., Jobson, T., Stroud, C., Young, V., Fried, A., and Wert, B.: Direct measurements of urban OH reactivity during Nashville SOS in summer 1999, J. Environ. Monitor., 5, 68-74, 2003.

Lou, S., Holland, F., Rohrer, F., Lu, K., Bohn, B., Brauers, T., Chang, C. C., Fuchs, H., Häseler, R., Kita, K., Kondo, Y., Li, X., Shao, M., Zeng, L., Wahner, A., Zhang, Y., Wang, W., and Hofzumahaus, A.: Atmospheric $\mathrm{OH}$ reactivities in the Pearl River Delta - China in summer 2006: measurement and model results, Atmos. Chem. Phys., 10, 11243-11260, doi:10.5194/acp-10-11243-2010, 2010.

Mao, J., Ren, X., Brune, W. H., Olson, J. R., Crawford, J. H., Fried, A., Huey, L. G., Cohen, R. C., Heikes, B., Singh, H. B., Blake, D. R., Sachse, G. W., Diskin, G. S., Hall, S. R., and Shetter, R. E.: Airborne measurement of $\mathrm{OH}$ reactivity during INTEX-B, Atmos. Chem. Phys., 9, 163-173, doi:10.5194/acp-9-163-2009, 2009.

Mao, J., Ren, X., Chen, S., Brune, W. H., Chen, Z., Martinez, M., Harder, H., Lefer, B., Rappenglück, B., Flynn, J., and Leuchner, M.: Atmospheric oxidation capacity in the summer of Houston 2006: Comparison with summer measurements in other metropolitan studies, Atmos. Environ., 44, 4107-4115, 2010.
Mao, J., Ren, X., Zhang, L., Van Duin, D. M., Cohen, R. C., Park, J.-H., Goldstein, A. H., Paulot, F., Beaver, M. R., Crounse, J. D., Wennberg, P. O., DiGangi, J. P., Henry, S. B., Keutsch, F. N., Park, C., Schade, G. W., Wolfe, G. M., Thornton, J. A., and Brune, W. H.: Insights into hydroxyl measurements and atmospheric oxidation in a California forest, Atmos. Chem. Phys., 12, 8009-8020, doi:10.5194/acp-12-8009-2012, 2012.

Mogensen, D., Smolander, S., Sogachev, A., Zhou, L., Sinha, V., Guenther, A., Williams, J., Nieminen, T., Kajos, M. K., Rinne, J., Kulmala, M., and Boy, M.: Modelling atmospheric OH-reactivity in a boreal forest ecosystem, Atmos. Chem. Phys., 11, 97099719, doi:10.5194/acp-11-9709-2011, 2011.

Nölscher, A. C., Williams, J., Sinha, V., Custer, T., Song, W., Johnson, A. M., Axinte, R., Bozem, H., Fischer, H., Pouvesle, N., Phillips, G., Crowley, J. N., Rantala, P., Rinne, J., Kulmala, M., Gonzales, D., Valverde-Canossa, J., Vogel, A., Hoffmann, T., Ouwersloot, H. G., Vilà-Guerau de Arellano, J., and Lelieveld, J.: Summertime total $\mathrm{OH}$ reactivity measurements from boreal forest during HUMPPA-COPEC 2010, Atmos. Chem. Phys., 12, 8257-8270, doi:10.5194/acp-12-8257-2012, 2012.

Ren, X., Harder, H., Martinez, M., Lesher, R. L., Oliger, A., Shirley, T., Adams, J., Simpas, J. B., and Brune, W. H.: $\mathrm{HO}_{\mathrm{x}}$ concentrations and $\mathrm{OH}$ reactivity observations in New York City during PMTACS-NY2001, Atmos. Environ., 37, 3627-3637, 2003a.

Ren, X., Harder, H., Martinez, M., Lesher, R. L., Oliger, A., Simpas, J. B., Brune, W. H., Schwab, J. J., Demerjian, K. L., He, Y., Zhou, X. L., and Gao, H. G.: $\mathrm{OH}$ and $\mathrm{HO}_{2}$ chemistry in the urban atmosphere of New York City, Atmos. Environ., 37, 3639-3651, 2003b.

Ren, X., Brune, W. H., Mao, J. Q., Mitchell, M. J., Lesher, R. L., Simpas, J. B., Metcalf, A. R., Schwab, J. J., Cai, C. X., Li, Y. Q., Demerjian, K. L., Felton, H. D., Boynton, G., Adams, A., Perry, J., He, Y., Zhou, X. L., and Hou, J.: Behavior of $\mathrm{OH}$ and $\mathrm{HO}_{2}$ in the winter atmosphere in New York city, Atmos. Environ., 40, 252-263, 2006a.

Ren, X., Brune, W. H., Oliger, A., Metcalf, A. R., Simpas, J. B., Shirley, T., Schwab, J. J., Bai, C., Roychowdhury, U., Li, Y., Cai, C., Demerjian, K. L., He, Y., Zhou, X., Gao, H., and Hou, J.: $\mathrm{OH}, \mathrm{HO}_{2}$, and $\mathrm{OH}$ reactivity during the PMTACS-NY Whiteface Mountain 2002 campaign: Observations and model comparison, J. Geophys. Res., 111, D10S03, doi:10.1029/2005JD006126, 2006b.

Sadanaga, Y., Yoshino, A., Kato, S., Yoshioka, A., Watanabe, K., Miyakawa, Y., Hayashi, I., Ichikawa, M., Matsumoto, J., Nishiyama, A., Akiyama, N., Kanaya, Y., and Kajii, Y.: The importance of $\mathrm{NO}_{2}$ and volatile organic compounds in the urban air from the viewpoint of the $\mathrm{OH}$ reactivity, Geophys. Res. Lett., 31, L08102, doi:10.1029/2004g1019661, 2004a.

Sadanaga, Y., Yoshino, A., Watanabe, K., Yoshioka, A., Wakazono, Y., Kanaya, Y., and Kajii, Y.: Development of a Measurement System of $\mathrm{OH}$ reactivity in the atmosphere by using a laserinduced pump and probe technique, Rev. Sci. Instrum., 75, 26482655, 2004b.

Schade, G. W., Goldstein, A. H., and Lamanna, M. S.: Are monoterpene emissions influenced by humidity?, Geophys. Res. Lett., 26, 2187-2190, 1999.

Seeley, J. V., Jayne, J. T., and Molina, M. J.: High-Pressure FastFlow Technique for Gas Kinetics Studies, Int. J. Chem. Kinet., 25, 571-594, 1993. 
Shetter, R. E., Junkermann, W., Swartz, W. H., Frost, G. J., Crawford, J. H., Lefer, B. L., Barrick, J. D., Hall, S. R., Hofzumahaus, A., Bais, A., Calvert, J. G., Cantrell, C. A., Madronich, S., Muller, M., Kraus, A., Monks, P. S., Edwards, G. D., McKenzie, R., Johnston, P., Schmitt, R., Griffioen, E., Krol, M., Kylling, A., Dickerson, R. R., Lloyd, S. A., Martin, T., Gardiner, B., Mayer, B., Pfister, G., Roth, E. P., Koepke, P., Ruggaber, A., Schwander, H., and van Weele, M.: Photolysis frequency of $\mathrm{NO}_{2}$ : Measurement and modeling during the International Photolysis Frequency Measurement and Modeling Intercomparison (IPMMI), J. Geophys. Res.-Atmos., 108, 8544, doi:10.1029/2002JD002932, 2003.

Sinha, V., Williams, J., Crowley, J. N., and Lelieveld, J.: The Comparative Reactivity Method - a new tool to measure total $\mathrm{OH}$ Reactivity in ambient air, Atmos. Chem. Phys., 8, 2213-2227, doi:10.5194/acp-8-2213-2008, 2008.

Sinha, V., J., W., Lelieveld, J., Ruuskanen, T. M., Kajos, M. K., Patokoski, J., Hellen, H., Hakola, H., Mogensen, D., Boy, M., Rinne, J., and Kumala, M.: OH Reactivity Measurements within a Boreal Forest: Evidence for Unknown Reactive Emissions, Environ. Sci. Technol., 44, 6614-6620, 2010.

Sinha, V., Williams, J., Diesch, J. M., Drewnick, F., Martinez, M., Harder, H., Regelin, E., Kubistin, D., Bozem, H., HosaynaliBeygi, Z., Fischer, H., Andrés-Hernández, M. D., Kartal, D., Adame, J. A., and Lelieveld, J.: Constraints on instantaneous ozone production rates and regimes during DOMINO derived using in-situ $\mathrm{OH}$ reactivity measurements, Atmos. Chem. Phys., 12, 7269-7283, doi:10.5194/acp-12-7269-2012, 2012.
Westberg, H., Lamb, B., Hafer, R., Hills, A., Shepson, P., and Vogel, C.: Measurement of isoprene fluxes at the PROPHET site, J. Geophys. Res., 106, 24347-24358, 2001.

Wolfe, G. M., Thornton, J. A., Bouvier-Brown, N. C., Goldstein, A. H., Park, J.-H., McKay, M., Matross, D. M., Mao, J., Brune, W. H., LaFranchi, B. W., Browne, E. C., Min, K.-E., Wooldridge, P. J., Cohen, R. C., Crounse, J. D., Faloona, I. C., Gilman, J. B., Kuster, W. C., de Gouw, J. A., Huisman, A., and Keutsch, F. N.: The Chemistry of Atmosphere-Forest Exchange (CAFE) Model - Part 2: Application to BEARPEX-2007 observations, Atmos. Chem. Phys., 11, 1269-1294, doi:10.5194/acp-11-12692011, 2011.

Yoshino, A., Sadanaga, Y., Watanabe, K., Kato, S., Miyakawa, Y., Matsumoto, J., and Kajii, Y.: Measurement of total OH reactivity by laser-induced pump and probe technique - comprehensive observations in the urban atmosphere of Tokyo, Atmos. Environ., 40, 7869-7881, 2006. 